"This is the peer reviewed version of the following article: [PAPERS IN REGIONAL SCIENCE, 2019, 98 (1), pp. $451-+(27)]$, which has been published in final form at

[https://rsaiconnect.onlinelibrary.wiley.com/doi/full/10.1111/pirs.12333]. This article may be used for non-commercial purposes in accordance with Wiley Terms and Conditions for Self-Archiving." 


\title{
Area-specific subsidies and population dynamics: evidence from the \\ Australian Zone Tax Offset*
}

\author{
Nathan Kettlewell \\ University of Sydney
}

\author{
Oleg Yerokhin \\ University of Wollongong
}

August 2017

\begin{abstract}
This paper studies the effect of the Zone Tax Offset (ZTO), a place based income subsidy implemented in rural Australia since 1945. The policy was intended to improve the welfare of inhabitants and provide an incentive for settlement. Our empirical approach exploits the geographical discontinuity in the eligibility for the subsidy to identify its causal effect on population growth. Using data on population by locality from the historical censuses we find that the ZTO had a positive but only temporary effect on population growth in the targeted areas.
\end{abstract}

JEL classification: D04, H24, J61, N90, R23

Keywords: place based policy, rural population, spatial regression, zone tax offset, income subsidy

Corresponding author: Nathan Kettlewell | email: nathan.kettlewell @ sydney.edu.au | address: School of Economics, Room 370, Merewether Building (H04), The University of Sydney, NSW, 2006, Australia.

*We would like to thank Terence Cheng, Denise Doiron, Olena Stavrunova, participants of the 2014 Labour Econometrics Workshop (Dunedin, New Zealand) and three anonymous reviewers for valuable feedback on this paper. We are especially grateful to Heidi Brown and Alexander Pescud from the University of Wollongong School of Earth and Environmental Sciences for significant assistance with the GIS component of this research. Any mistakes are our own. 


\section{Introduction}

Economic transformation of rural areas has been an active area of research in regional and spatial economics throughout the last century (Irwin et al, 2010). Historically this research has been motivated, among other factors, by the observed population decline in rural areas, which is a pervasive phenomenon across countries, particularly during periods of economic development (Taylor and Martin, 2001).

In this paper we assess a historical policy initiative implemented in Australia during a period of rural population decline to answer whether a relatively modest income subsidy can influence the trajectory of local population growth. The policy we study - the Zone Tax Offset (ZTO) began in 1945 as a tax deduction available to people living in certain remote and rural areas of the country.

We expect that policy makers will be interested both in whether they can use income support programs to directly influence local population growth, as well as whether they can provide income support to local populations without influencing population growth. There is also likely to be interest around the conditions under which such policies are effective. As we document below, evaluations of similar place based policies within developed countries have pointed to mixed results. There is also limited evidence on rural programs. The policy we study was implemented during a period of economic structural change, whereby employment was shifting from agriculture towards manufacturing and the target region was losing population as a result. These conditions provide a challenge to policy makers that is likely to be particularly relevant for developing economies in Asia, South America and Africa in the coming decades. Intervening to improve rural welfare may have the unintended consequence of restricting the flow of labour to 
more productive parts of the economy. On the other hand, this may be desirable if policy makers are sufficiently concerned about the sustainability of the rural economy.

Typically place based policies target economically disadvantaged areas, usually poor urban neighbourhoods, and aim to increase local employment and earnings. Empirical literature remains divided on whether these policies achieve their goals ${ }^{1}$. Busso et al (2013) report significant employment effects of the US federal Empowerment Zones (EZ) program. Ham et al (2011) also find positive effects for employment and poverty reduction from the EZ program, as well as other large-scale place based policies. Hansen (2009), on the other hand, finds a significant positive effect on property values and no effect on employment and poverty rates. Similarly, Neumark and Kolko (2010) and Reynolds and Rohlin (2015) also find no evidence that the EZ program benefited low income residents in target areas. Freedman (2013) uses and RD design and finds that EZ policy has had a positive effect on population level in Texas. Kline and Moretti (2014) evaluate the aggregate effects of the Tennessee Valley Authority on the US economy and find that gains to the local economy exceeded spill-over costs to other regions.

In Europe, Gobillon et al (2012) and Beheghel et al (2015) find no empirical evidence of the effectiveness of place based policies in France, while Jofrey-Monseny (2014) concludes that a place based unemployment benefit in lagging rural areas in Spain reduced the rate of population decline by triggering both in-migration into the treated regions and reducing out-migration. Overall, there is scope for more research on rural schemes to evaluate the relationship between placed based policy performance and rurality.

\footnotetext{
${ }^{1}$ See Neumark and Simpson (2014) for a comprehensive survey of this literature.
} 
The studies by Freedman (2013) and Jofrey-Monseny (2014) are of particular relevance for this paper as they specifically at the effects of place based policies on population levels of the targeted areas. This focus can is justified by the fact that population can be an important determinant of economic development of rural areas due to the economies of scale which determine firm location decisions.

This paper is also related to the large interdisciplinary literature on rural development. Population dynamics of rural areas is a complex process that goes beyond a simple story of declining share of agricultural and manufacturing employment (Irwin et al, 2010). Because the areas targeted by the policy studied in this paper are located in remote or rural regions, many of which have harsh climates, the strand of literature on natural amenities as drivers of population dynamics (e.g. Deller et al, 2001) is of direct relevance. Given the natural tendency of these areas to lose population as income per capita grows, policymakers face difficult questions about whether it is worthwhile to fight this tendency through place based subsidies (which is a similar predicament to that posed by structural change). Economists are generally sceptical of such policies, given that under the spatial equilibrium framework their benefits accrue to the owners of fixed factors such as land.

The ZTO that we study has several distinct features that make it an interesting case study of how government programs can influence economic outcomes in specific geographical areas. First, the stated goals of the policy were somewhat modest compared to most other placed based government programs. The period encompassing the 1930s and early 1940s had been characterized by a rapid population decline in rural and regional Australia driven by the sectoral shift away from agriculture and towards manufacturing (Connelly and Lewis, 2010). It was hoped that the ZTO would reverse this trend by creating incentives for people to stay in the 
regional and remote areas of the country. This contrasts with more ambitious goals of increasing employment and productivity of the targeted areas commonly seen in the more recent place based policies implemented in the US and Europe. Second, the way the ZTO was implemented is somewhat distinct from the usual practice that we see today, in which the target areas are typically carefully selected based on their socio-economic characteristics. In contrast, the ZTO singled out two vast geographical regions of the country (called Zone A and Zone B, see figure 1) to be the target areas based on a set of characteristics related to their remoteness and unfavourable living conditions. By doing this, policymakers effectively created a geographical border at which eligibility for the tax offset changes discontinuously. To the best of our knowledge, there have been no previous evaluations of the ZTO.

To estimate the effect of the ZTO on population growth we use two modelling approaches, utilizing different aspects of our data. First we exploit the temporal aspect and estimate a number of difference-in-difference (D-in-D) specifications. We expect that areas that are geographically proximate to one another are more likely to be similar with regards to underlying determinants of population growth. Consequently, our analysis is based on the samples of localities that are located within 100, 150, 200 and 250 kilometres $^{2}(\mathrm{~km})$ from the ZTO boundary in the states of New South Wales (NSW) and Queensland (QLD), where the policy boundary does not straddle major cities. Next we take advantage of the spatial discontinuity created by the policy boundary and estimate a semi-parametric spatial Regression Discontinuity (RD) model with a twodimensional running variable based on the geographical coordinates of each locality. This strategy requires that the counterfactual densities of all important determinants of population

\footnotetext{
${ }^{2}$ Smaller bandwidth turned out to be impractical due to sample size limitations. While these bandwidths may appear large, given the remoteness of the localities within our sample we do not view this as a serious limitation. This is discussed further in section 5 .
} 
growth in the treatment and control groups are continuous at the policy boundary. We provide support for this assumption by testing the continuity of important geographical variables at the policy boundary and conducting a falsification test on pre-policy data.

Our results indicate a relatively large but temporary impact of the ZTO on population growth. This result is consistent and of similar magnitude across D-in-D and RD specifications. We estimate that between 1945 and 1947, the ZTO slowed down population decline by 5 to 7 percentage points per year. However, we do not find evidence of sustained differences in population growth in the subsequent years, which implies the ZTO caused a one-off shift in the population trajectory. This result is robust to restricting our sample to smaller bandwidths around the ZTO boundary. It is also consistent with the theoretical predictions arising from the spatial equilibrium framework. We therefore conclude that the ZTO was effective in slowing the population decline in target areas, but only in the short run.

The remainder of the paper is organized as follows. Section 2 describes institutional details of the ZTO program. In section 3 we present a conceptual framework for our empirical analysis. Section 4 describes the data and section 5 details our estimation framework. Section 6 presents empirical results. Section 7 concludes by discussing the findings of the paper and their policy implications.

\section{The Zone Tax Offset Program}

During the final months of World War II in 1945, the Australian government announced a moderate package of tax reductions. The most economically significant of these announcements was a tax deduction that would be made available to people living in prescribed rural and remote areas (Adelaide Advertiser, 3 May 1945, pg. 7), which we address by its modern title, the ZTO. 
The original value of the tax deduction available to people in the areas we study was 20 Australian pounds, or AUD\$1,291 in 2013 prices $^{3}$. People living in these areas were able to reduce their taxable income by this amount.

The ZTO proved to be highly contentious and seems to have attracted significant publicity at the time. While supportive of general efforts to reduce taxation, the main opposition party were vocally opposed to the policy. There was concern the policy would be unfair because the arbitrary nature of the policy boundaries meant that "it would give rise to intolerable anomalies along the border of each division line and taxpayers with identical living conditions would be subject to differential taxation" (Adelaide Advertiser, 3 May 1945, pg. 7). In addition, concerns were raised about the precedent created by deviating from spatially consistent income taxation and whether the payment was valid under the Australian constitution ${ }^{4}$.

Despite its political opposition, the ZTO was legislated and came into effect on 1 July 1945. The policy was described by the then Treasurer Robert Chifley as "compensation for the disabilities of uncongenial climatic conditions, isolation, or relatively high living costs" (Chifley, 1945). The policy created three taxation 'zones' that have remained largely unchanged since they were first introduced ${ }^{5}$. Zone A represented the most remote areas of the country. Zone B comprised rural areas considered less remote and attracted a smaller deduction. The remainder of

\footnotetext{
${ }^{3}$ Regional CPI figures are not available in Australia and this figure is derived using national prices. Note Australia switched to decimal currency in 1966.

${ }^{4}$ Specifically, there were concerns that the policy may violate sub-sections 51(2) and section 99 of the Australian constitution, which effectively require that the Commonwealth government cannot provide preferential treatment between States or parts thereof in matters of taxation, law, regulation, trade, commerce or revenue. Legal advice provided to the government at the time indicated the policy was constitutionally valid.

${ }^{5}$ In 1956 Zone A was extended to include some areas that were previously a part of Zone B. This policy change did not capture any areas in our sample. 'Special zone rates' were created in 1982 to provide higher benefits to people living in either Zone A or Zone B who were in excess of $250 \mathrm{~km}$ by the shortest practicable surface route from the centre of the nearest population centre of 2,500 or more. This policy change falls outside our sample period.
} 
the country was not entitled to the ZTO. Figure 1 contains a map of all of these zones. Zone A is roughly comprised of northern Western Australia, the Northern Territory and northern QLD. Zone B comprises areas in mid and western QLD, western NSW, most of South Australia north of Adelaide and most of southern Western Australia north of Perth. Its border also runs through Tasmania. For reasons that will be discussed shortly, this paper focuses on the policy effect in Zone B in NSW and QLD only.

[figure 1 here]

While the ZTO boundaries were intended to target certain characteristics, in practice the Zone B boundary in NSW and QLD that we use in this study used existing administrative units (Shires and Counties) to divide the country. There is no obvious reason to expect any discontinuity in characteristics linked to population growth at the borders of these administrative units $^{6}$. Shire boundaries in QLD have some practical role, since they determine the governance region for local government. However, since the primary role of local government in Australia is service delivery, and moreover there is no reason to believe that the performance of local government should be systematically different across the Zone B boundary, this is not a serious concern. NSW counties are an obsolete spatial unit and had no real power when the ZTO was introduced. Later we formally test for continuity of characteristics at the Zone B boundary.

To be eligible for the ZTO a person needed only to be living in one of the zones. 'Living' was defined by having a home in the relevant zone that the person occupied for at least half the financial year. Because the ZTO was delivered by way of a tax deduction, only those people with

\footnotetext{
${ }^{6}$ In our review of the institutional history of the ZTO, we have found no evidence to suggest the policy boundaries were used for any other policy purpose during our study period. Soldier settlement schemes in NSW and QLD following WWII were not linked to the ZTO and did not systematically target the treatment zone.
} 
a tax liability could actually benefit from it. This also meant that the policy was regressive, with the benefit being roughly equal to the value of the deduction times the taxpayer's marginal tax rate. High income earners, who faced the highest marginal tax rates, received the greatest concession. This aspect of the policy was reversed in 1975-76 when the gross benefit was reduced but paid instead as a tax offset (i.e. as a fixed reduction in the recipient's tax liability). This policy change marked the decline in the real value of the ZTO. Today, its base value for people living in Zone B is negligible (\$57), although it can be larger depending on how many dependants the recipient has.

As mentioned above, the original value of the tax deduction available to people living in Zone B was AUD\$1,291 in 2013 prices. The benefit was paid on an individual basis, meaning high income dual income households could receive the highest benefits (since they had two incomes to offset and faced the highest marginal tax rates). In 1952 recipients were able to apply to have the ZTO paid as a reduction in tax payable from paycheque to paycheque rather than a lump sum at the end of the financial year. There were increases to the ZTO in 1956-57 and 195859. A timeline showing the real value (adjusted for inflation) of the deduction over the financial years $1945-46$ to $1975-76$ is shown in Figure 2. Since prices have risen by much less than wages over time, Figure 2 probably provides a pessimistic view of how workers valued the ZTO in its early years. As an illustration, the nominal average wage for a male full-time worker was roughly 335 pounds in December 1946 (Australian Bureau of Statistics, 1947). A 20 Australian pounds tax deduction would therefore be the equivalent of around 6 per cent of the average 
wage. In 2014, for a taxpayer earning roughly the average wage this would translate to an annual benefit of around $1,443^{7}$ Australian dollars in 2013, or a 2 per cent wage increase.

[Figure 2 here]

It is difficult to predict how people might have valued the ZTO in Zone B when it was first introduced, particularly since it does not appear particularly generous when looking at its real value for a single year. There are a few reasons why we may expect this payment to have had a real impact of people's location choices. Firstly, as shown in the previous paragraph, the payment appears considerably more generous when framed through wages. Secondly, the payment was ongoing and therefore potentially offered a lifetime advantage to living in the zone (it is also possible that residents would have expected the value of the payment to increase in the future, although this did not eventuate in real terms in the case of Zone B). Thirdly, while the primary goal of the ZTO was to provide welfare, politicians at the time also saw it as providing an incentive for settlement ${ }^{8}$. Finally, we show later that at the time the ZTO was introduced, the regions around the Zone B boundary in NSW and QLD were undergoing substantial population decline. We may expect asymmetry in the incentive effects for people deciding to 'stay' relative to inbound movers since stayers would be expected to have greater knowledge of the payment,

\footnotetext{
${ }^{7}$ This calculation is based on a wage of $\$ 74,000$, which is roughly the national average wage for a full-time employee (male and female) in 2014. Specifically, $\$ 74,000 * 0.06 * 0.32 .5=\$ 1,443$ where 32.5 per cent is the marginal tax rate for a worker earning $\$ 74,000$ in 2014. In 1946-47 the tax schedule consisted of progressive linear tax brackets rather than the horizontal tax brackets in place today. At an income of $£ 335$, a marginal tax rate of around 20 per cent would have been payable. The top marginal tax rate payable was significantly higher than today (72.5 per cent compared to 46.5 per cent today).

${ }^{8}$ For example, the explanatory memorandum to the original legislation states "the allowance of an income tax concession to all taxpayers residing in such areas would tend to encourage settlement in those areas". Government member of Parliament Herbert Johnson was quoted in the Adelaide Advertiser (4 May, 1945, pg. 3) as saying in defence of the ZTO that "people should be encouraged to go into the back country and the Government must give them every encouragement to go there".
} 
may perceive the payment as a signal of government support for their region and would not be subject to the same uncertainty about life in Zone B.

While the ZTO policy remains in place today, the magnitude of the offset is small (on the order of 50 Australian dollars) and cannot provide a meaningful economic incentive for relocation into remote and rural areas. For this reason, we focus on the early period when the policy presented a significant economic incentive. Due to changes in census geographical classifications, this paper considers its impact in the first 16 years after introduction. Coincidentally, this is also the period when the ZTO was most generous. Consequently, failure to find a persistent policy effect within the first 16 years can likely be extrapolated to the present day.

\section{Conceptual framework}

To understand what kind of impact a policy like the ZTO could have had on population levels in regional Australia we rely on the spatial equilibrium framework (Rosen, 1976; Roback, 1982). This framework considers a population of economic agents with homogeneous preferences spread in space across different localities or regions. All agents are assumed to maximized the present value of lifetime utility, and labour and housing markets are assumed to be competitive and in equilibrium at any point in time. The key insight of the model is quite intuitive: if the cost of migration is relatively low, the lifetime and period-by-period utility obtained by the agents must be constant across space. 
Following Glaeser and Gottlieb (2008), suppose that the indirect utility function of an individual in location $i$ can be written as $V\left(W_{i}, P_{i}, \theta_{i}\right)$, where $W_{i}$ is income in location $i, P_{i}$ is the price of housing and $\theta_{i}$ is the quality of life parameter capturing the utility flow from local amenities. An income subsidy in location $i, S_{i}$ will increase income in location $i$, thus making it more attractive compared to other locations. This leads to migration which drives up the prices of non-tradables (in this case housing) until the agent's utility in location $i$ is again equal to the utility at all other locations and the spatial equilibrium is restored. Formally we have

$$
\frac{\partial W_{i}}{\partial S_{i}}+\frac{V_{w}}{V_{p}} \frac{\partial P_{i}}{\partial S_{i}}=0
$$

In equilibrium, if each agent consumes one unit of housing we have $\frac{\partial W_{i}}{\partial S_{i}}=\frac{\partial P_{i}}{\partial S_{i}}$, i.e. income increases are capitalized into the price of housing. In the new equilibrium the total population of locality $i$ is higher than it was before (except for the extreme case in which the supply of land and housing is perfectly inelastic). However, the tax subsidy does not result in sustained population growth. The lack of historical data on the house prices in regional and rural locations does not allow us to test explicitly the prediction that the subsidy would be capitalized into housing prices. However we can test the prediction of this theoretical framework that the ZTO would lead to higher population growth in the period immediately after its introduction, but then return to trend after this. 


\section{Data}

Historical census data was used to construct a panel of localities for the period 1921 to 1961. The census years for this period were 1921, 1933, 1947, 1954 and 1961. The year 1921 is the first year data on localities was collected and 1961 is 16 years after the ZTO was introduced, allowing for short- and medium-run effects to be estimated. 'Localities' are an ideal spatial unit for studying the effect of the ZTO policy. They are defined by generally accepted boundaries for towns or villages according to the Australian Bureau of Statistics. Their growth is therefore not restricted to being within some fixed perimeter. The major limitation of using localities is that we only have limited data on the population at this level. There is more data at the next tier spatial unit, local government areas (LGAs). These areas are roughly equivalent to regions controlled by separate local councils. The complication is that LGA boundaries changed from census to census so that population growth and changes in other LGA variables over time cannot be accurately measured. The number of LGAs is also much smaller than the number of localities. For this reason we do not use LGA data as an observational unit, although we do use some LGA data for descriptive purposes and as controls in our spatial RD models.

Geographic Information Systems (GIS) software was used to generate a list of localities within $250 \mathrm{~km}$ either side of the Zone B boundary in NSW and QLD. This list was then checked against the Australian Taxation Office's list of Zone B localities. While payments to Zone A residents were much higher, and we may therefore expect any policy effect to be more pronounced there, only a very small number of localities were proximate to the Zone A border, which led us to focus exclusively on Zone B. Similarly, we use data only on localities in NSW and QLD and exclude South Australia and Western Australia. This is because the Zone B border was effectively drawn around the outskirts of the major cities of South Australia and Western 
Australia (Adelaide and Perth respectively). Consequently, localities outside the border are unlikely to be an appropriate control group for the localities inside the border in those states. We also do not use data from Tasmania on the basis of its uniqueness as a small separate island. Localities within $30 \mathrm{~km}$ of the coast were also excluded to ensure sample homogeneity. This reduced our pooled sample by 347 localities, or roughly 20 per cent. These localities (all in QLD) typically belonged to dense clusters of population, whose growth one would expect to be highly interrelated. To exclude variability imposed by a small number of localities that experienced extraordinary changes in population between some of the censuses, we dropped any locality that experienced growth of plus or minus three standard deviations from the mean at any point in the sample period. This reduced our pooled sample by 25 localities. The importance of these restrictions is discussed further in section 6. Finally, only localities with a population greater than 50 in the relevant census years were kept. This was motivated by two reasons. First, the Australian Bureau of Statistics did not collect data on localities with populations less than 50 in some years; and second, due their small size these localities could have very volatile population growth rates, thus reducing the precision of our estimates. This reduced our pooled sample by 48 localities.

In many cases, localities were divided by Census into two separate parts - a main section and a near section (i.e. dwellings in the surrounding areas of a town but without a separate recognized name). 'Main' and 'near' localities were always amalgamated into a single locality. We also amalgamated observations where the north, south, east, west or similar part of the locality was entered as a separate observation to the main locality in the census (except on very few occasions where it was clear by their geographical coordinates that the localities were not 
reasonably close to each other). Our final dataset consists of an unbalanced panel of 398 unique localities of which 277 are present in every year ${ }^{9}$.

Table 1 provides sample counts for the localities in what would become Zone B (treatment) and the localities outside Zone B (control) across different distances to the Zone B boundary in 1933 (the most recent census prior to the introduction of the ZTO). Three hundred and fifty two localities are in our sample in 1933. There were more localities in the control group, although the sample becomes more balanced for smaller distance buffers around the boundary. Figure 3 presents the map of the estimation sample in the $250 \mathrm{~km}$ buffer.

[Figure 3 here]

Descriptive statistics are provided in Table 2. Only population and percentage of males are at the localities level. Data on industry structure were approximated by the industry structure for the LGA that the locality predominantly belonged to. In some cases localities did not belong to any LGA or belonged to multiple LGAs and it was impossible to assign them correctly ${ }^{10}$. For this reason the sample size is smaller for these variables. Throughout our analysis, we report results for samples within a 250, 200, 150 and $100 \mathrm{~km}$ buffer around the Zone B boundary. This exercise is important to our identification strategy since we expect localities that are geographically proximate to differ less in terms of unobservable determinants of population growth. The trade-off is that we face an increasingly smaller sample size and the resulting loss of precision of our estimates.

\footnotetext{
${ }^{9}$ The panel is unbalanced due to the sample restrictions as well as the fact that some towns are formed during the sample period. In sensitivity analysis available on request, we repeated our empirical analysis on the balanced sample of localities. These results are similar to those presented in the paper and our conclusions are not sensitive to the use of balanced/unbalanced sample.

${ }^{10}$ When localities belong to multiple LGAs, the census does not indicate what proportion of inhabitants live in each LGA, ruling out any sort of weighting exercise.
} 
[Table 1 here]

While there are statistically significant differences between treated and control localities in proportion of employment in manufacturing, the relatively small share of manufacturing in both groups leads us to believe that these differences are not economically significant. Both control and treatment localities are predominately agricultural with a small mining and manufacturing sector, have a male gender imbalance and similar employment rate on average in 1933. Mean population size is higher in the Zone B group, except for the $100 \mathrm{~km}$ sample. The standard deviation of population size is also much higher for this group. The higher mean is partly driven by a relatively higher number of larger localities outside the $100 \mathrm{~km}$ buffer. These observations were not dropped from the analysis because we do not see any reason why the population response should be restricted to smaller areas. Moreover, most of our discussion focuses on the $100 \mathrm{~km}$ buffer results. Since we take a log transformation of the population variable, the influence of outliers is moderated.

[Table 2 here]

Figure 4 presents the raw trends in population growth over the sample period for the ZTO and control localities. The growth rates were annualised for comparability. Localities in both groups experienced similar trends in population growth, namely a significant dip between 1933-1947 followed by population resurgence in the 1947-1954 period. The growth dip in 1933-47 did not mirror the national growth pattern, which was steady over the period. It coincides with a period of structural change in the Australian labour market away from agriculture and towards manufacturing. From 1930 to the end of WW2, agriculture's share of employment fell from around $25 \%$ to $15 \%$, with an almost inverse change in the share for 
manufacturing (Connolly and Lewis, 2010). The stagnant population growth for rural NSW and QLD, which included negative population growth for many areas, is therefore unsurprising. These economies were predominately agricultural with negligible manufacturing shares in both 1933 and $1947^{11}$. Against this, we may expect the ZTO to have acted as an incentive to 'stay' in remote and rural localities as much as an incentive for prospective movers.

There are some interesting results that are robust to the different buffers around the ZTO boundary. First, ZTO localities grew more slowly between 1921 and 1933 . What this implies about potential endogeneity of the ZTO border is unclear. On the one hand, this result could imply that ZTO localities were selected based on unfavourable conditions for population growth. This kind of selection bias would tend to attenuate our treatment effect estimates. On the other hand, if the slow growth between 1921-1933 was followed by a regression to the mean effect unrelated to the ZTO, then selectivity bias could go in the other direction. In what follows we show that the difference in population growth in the 1921-1933 period is not statistically significant when we condition on geographical location in the spatial RD framework, which implies that our modelling approach is able to account for this potential selectivity bias. We can also see that treated localities experienced higher annualised growth between the 1933 and 1947 censuses (the end date of this period comes two years after the ZTO was introduced). In 1954 there were no significant differences while there is some evidence of ZTO localities again growing more strongly between 1954-1961. We will show later that the descriptive results for the 1933-1947 period are largely confirmed by more rigorous analysis, while there is weaker evidence for a growth differential in later years.

\section{[Figure 4 here]}

\footnotetext{
${ }^{11}$ The employment mix in 1947 is similar to that for 1933 (shown in Table 2).
} 


\section{Econometric framework}

There are two main approaches we use to identify the effect of the ZTO on population growth. The first one takes advantage of the temporal dimension of our data by applying D-in-D methods to estimate the effect of the policy. This approach allows unobserved determinants of population growth to be correlated with the ZTO assignment under the assumption that these unobserved variables are constant over time. The second approach is the spatial RD design, which potentially can accommodate selectivity along both transient and fixed dimensions but is more data intensive. The identifying assumption in this case is that localities in small neighbourhoods around the Zone B boundary are similar in all important dimensions except for the assignment of the treatment status. Consequently, any differences in growth outcomes can be attributed to the effect of the ZTO. By estimating the population impact of the ZTO using D-in-D and spatial RD methods, we can assess the sensitivity of our results to different identifying assumptions.

Given the length of time between the consecutive censuses, the identifying assumption we need to impose in the spatial RD model is more plausible than for the case of D-in-D in our opinion. Even if the boundary was drawn to target areas with certain characteristics, it seems unlikely that the boundary would have been drawn with such precision that at every point localities that fall just inside it differ significantly from those just outside it, thereby making the $\mathrm{RD}$ design inappropriate ${ }^{12}$. However, RD also requires a reasonable number of observations to fall close to either side of the threshold. Our sample region is made up of a number of small,

\footnotetext{
${ }^{12}$ Note this assertion mirrors sentiment of opposition politicians at the time (see section 2).
} 
spatially disjointed localities and consequently this requirement may not be fully met. As a result, we consider carefully the combined results of our D-in-D and spatial RD models when drawing conclusions.

\subsection{Diff-in-Diff models}

The ZTO commenced in July 1945. The closest censuses to either side of this date were 1933 and 1947. The model specified below is therefore estimated treating 1921-1933 as the pretreatment period and 1933-47, 1947-54 and 1954-61 as the post-treatment periods. The main specification that we use is the standard D-in-D model with multiple post-policy periods:

$$
\Delta y_{i t}=\alpha_{0}+\sum_{\tau=1}^{3} \alpha_{1 \tau} \gamma_{\tau}+\alpha_{2} D_{i}+\sum_{\tau=1}^{3} \beta_{\tau}\left(\gamma_{\tau} * D_{i}\right)+\delta x_{i t-1}+\varepsilon_{i t}
$$

Here, $y_{i t}$ denotes the $\log$ of population in locality $i$ in period $t$, and $\Delta y_{i t}$ is the population growth of locality $i$ between time periods $t-1$ and $t$, which in our case correspond to the two adjacent census dates. $\gamma_{\tau}$ denotes the indicator for each of the three post-treatment periods, $D_{i}$ is the binary indicator of the ZTO status, and $x_{i t-1}$ is a vector of location specific covariates at the start of the period. The effect of the ZTO on population growth is identified by the parameters $\beta_{\tau}$ under the assumption that the growth rates of the localities inside and outside Zone B follow the same time trend. This assumption can often be tested by observing the change in the outcome variable prior to policy introduction. Unfortunately, because localities data was only collected for two censuses prior to introduction of the ZTO (giving us one observation for population growth), we have insufficient data to perform such a test. One way we compensate for this is to restrict our sample to increasingly smaller buffers around the continuous Zone B boundary. The idea 
behind this is that geographically proximate localities are likely to be similar and therefore it is more plausible that these groups would experience similar trajectories in population growth in the absence of policy intervention. While our buffers may appear large relative to those used by others who have adopted this method (our smallest buffer includes localities within $100 \mathrm{~km}$ each side of the boundary) we do not believe this is unreasonable. Our sample is comprised of remote and rural localities that are all several hours drive from a major population centre ${ }^{13}$. It is therefore reasonable to expect any changes in characteristics between localities that are one or two hours drive away from each other to be relatively subtle.

The model specified in equation (1) restricts the relationship between our covariates and population growth to be constant over time. This can be easily relaxed by interacting them with time fixed effects, as we do in our empirical analysis. We also estimate a version of the model with added locality fixed effects as a robustness check. This potentially richer model relaxes the assumption that the difference in time invariant characteristics between the treated and control localities is constant over the whole sample period and allows each individual locality to have its own fixed effect. In each of the D-in-D models the vector of controls $x_{i t-1}$ includes a cubic polynomial in log population level in period $t-1$. It is likely that current population will influence future population growth but not necessarily in a linear manner. We also control for the percentage of the population that is male since gender ratio may also influence population growth through the marriage market, conflict, industry evolution or a combination of these effects. We are limited by the fact that these are the only variables we observe at the locality level. Note that even though we include industry structure variables observed at the LGA level

\footnotetext{
${ }^{13}$ Even in our largest buffer $(250 \mathrm{~km})$, the closest town to Brisbane (QLD's state capital) is more than three hours' drive by modern road. The closest town to Sydney (NSW's state capital) is a five-hour drive.
} 
by assigning values based on the LGA the locality primarily belonged to ${ }^{14}$ in our spatial RD specification, we cannot control for industry in our D-in-D models because LGAs are not a stable spatial unit over time - their boundaries changed from census to census.

\subsection{Spatial RD model}

The fact that the ZTO treatment is a function of geographical location suggests that a regression discontinuity strategy can be used to estimate the effect of the ZTO policy on population growth, with the running variable being some measure of geographical proximity. The two dimensional nature of space makes specifying a running variable more complicated than in the standard one dimensional RD case. An intuitive approach would be to use 'distance to the border' as a running variable. However, this approach is flawed since it effectively reduces space to a single dimension. It treats localities that are a similar distance to the border, but potentially far from each other, as geographically proximate. While this can be potentially dealt with by dividing the boundary into smaller segments, we choose to deal with the multidimensional nature of the discontinuity created by the ZTO policy directly. We first follow Dell (2010) and utilize the semi-parametric multidimensional RD model by flexibly controlling for geographical coordinates of the localities in our sample. Our running variable is therefore a function of geographical coordinates ${ }^{15}$ that captures the relationship between population growth and space.

\footnotetext{
${ }^{14}$ This was a somewhat ad hoc exercise and undoubtedly some measurement error was introduced as a consequence. In most cases, localities belonged to a single LGA. In cases where a locality belonged to multiple LGAs, it was generally assigned to the LGA that the main part of the locality belonged to if the locality was divided into a 'main' and 'near' section. Where the main section belonged to multiple LGAs, the observation was simply dropped. Our main spatial RD results do not include these controls.

${ }^{15}$ We used the Universal Transverse Mercator (UTM) coordinate system for this purpose. The UTM coordinate system is a two dimensional Cartesian system, which has the advantage over basic latitude and longitude in that unit changes in its values correspond to roughly equal unit changes in Euclidean distance. This is desirable since we require our coordinates to control for spatial proximity of different localities. In practice, using latitude and longitude produced almost identical results and did not affect our conclusions.
} 
We experiment with a more flexible specification by adding higher order and cross-product terms. Formally, the model we estimate is given by

$$
y_{i t}={ }_{0}+D_{i}+f\left(c_{1 i}, c_{2 i}\right)+{ }_{i t}
$$

where $c_{1 i}$ and $c_{2 i}$ are the geographical coordinates (horizontal and vertical values in the UTM Cartesian system) of the location $i$. These are entered into the model as independent variables as described below.

In addition to this specification we also estimate a series of models controlling for observed location specific covariates as well as additional controls for industry structure (discussed in the previous subsection) and a dummy variable for NSW. It turns out that the results are not affected significantly by the inclusion of covariates. For this reason we focus on the main specification given in (2) and present the results of the models which include covariates in the Appendix. We consider the following specifications for the running variable $f\left(c_{1 i}, c_{2 i}\right)$ :

Linear polynomial $-f\left(c_{1 i}, c_{2 i}\right)=a_{1} c_{1 i}+a_{2} c_{2 i}+a_{3} c_{1 i} c_{2 i}$

Quadratic polynomial $-f\left(c_{1 i}, c_{2 i}\right)=a_{1} c_{1 i}+a_{2} c_{2 i}+a_{3} c_{1 i} c_{2 i}+a_{4} c_{1 i}^{2}+a_{5} c_{2 i}^{2}+a_{6} c_{1 i}^{2} c_{2 i}+a_{7} c_{1 i} c_{2 i}^{2}$

The identifying assumption needed for our spatial RD model to produce causal estimates of the policy effect is that the densities of all important determinants of population growth in the treatment and control groups should be continuous at the Zone $\mathrm{B}$ border. Given its semi-parametric nature, the spatial RD model is more data intensive compared to the D-in-D specification discussed above. With the limited number of observations available in the historical 
census data, our spatial RD results might in some cases lack precision. Hence we tend to consider carefully the combined results from the two approaches when drawing our conclusions.

Our baseline approach is to estimate (2) by ordinary least squares (OLS). As with the D-in-D analysis, we consider the sensitivity of our results to different buffers around the Zone B border. This is natural in an RD setting - we essentially face a trade-off between efficiency and bias with our choice of buffer (Lee and Leimux, 2010). A larger buffer uses more data and is therefore more efficient; however, with a smaller buffer it is more likely that a simple linear or quadratic control function can pick up the relationship between space and population growth. Ideally, our results will not change significantly as we vary the buffer from $250 \mathrm{~km}$ to $100 \mathrm{~km}$.

An alternative to OLS is to use a matching estimator. There are some advantages to using a matching estimator in this context. In particular, matching is conceptually simple and allows us to quantify the treatment effects for individual localities based on their geographic proximity to their control. OLS estimates the jump in population growth for geographically close localities across the Zone B border but in a non-transparent way. Matching achieves this directly and we can assess our confidence in the spatial RD results by looking at the consistency of results for localities that are geographically close to each other (which are likely to more reliable) with the overall estimated treatment effect.

For these reasons we augment our baseline spatial RD results by also estimating the policy effect using nearest-neighbour matching. Covariates in the matching algorithm are a linear polynomial of coordinates and $\log$ population in the base year ${ }^{16}$. Matching does not make sense

\footnotetext{
${ }^{16} \mathrm{We}$ include population as a control because it turned out to be a strong predictor of population growth (see Tables A1-A4). Our results are similar and conclusions unchanged if we exclude this control.
} 
for localities far from the Zone B border so this model is only estimated for localities within a $100 \mathrm{~km}$ buffer.

\subsection{Spatial RD: testing the validity of the identifying assumptions}

The spatial RD design identifies the policy effect under the assumption that localities in a small neighbourhood around the ZTO border are similar in the relevant dimensions except that one group is subject to the ZTO policy while the other is not. As discussed above, the way in which the ZTO boundary was drawn leads us to believe that there should be no systematic differences in localities that straddle its border. It is standard to test this assumption by looking at the continuity of geographical variables that could potentially affect population growth at the border (Dell, 2010). In particular, we test for the discontinuities of two exogenous characteristics: elevation and average annual rainfall over the period 1946-1955. Findings in the hedonic pricing and spatial equilibrium literature suggest that climate indicators, such as precipitation, are important determinants of quality of life (e.g. Graves et al, 1980; Hoehn et al, 1987; Blomquist et al, 1988; Deller et al, 2001); elevation is a strong determinant of climate and is therefore also likely to be important. Observations for elevation and rainfall were collected at the centroid of $20 \times 20 \mathrm{~km}$ grids that fell within $25 \mathrm{~km}$ of the Zone B boundary. As shown in Table 3, we cannot reject the null that the mean elevation and rainfall differs between observations across the boundary. ${ }^{17}$

A second test is to estimate the spatial RD model on pre-treatment data as a kind of placebo test. If the model accounts for the endogeneity of the treatment, then there should be no 'policy

\footnotetext{
${ }^{17}$ We also tested whether these differences are significant after conditioning on geographical coordinates (this addresses the concern that, for example, there are large differences between spatially proximate localities across the boundary but these differences offset each other across the entirety of the border). Even with these controls - using either a nearest-neighbour matching estimation approach or linear control function - we find no statistically significant difference in elevation or rainfall.
} 
effect' in the pre-treatment period. The results of this exercise are presented in the first panel of Table 6, where the spatial RD model is estimated for the period 1921-33. There is no evidence of a population growth differential between the treatment and control groups in that period, supporting our approach. Even though the standard errors are quite large, the estimated coefficients are in most cases close to zero and sometimes negative.

The second common threat to internal validity in the RD design is the manipulation of the running variable. In the present context this threat takes the form of what we call "localised migration": the hypothetical situation in which workers in the untreated locations living very close to the Zone B boundary respond to the policy by moving inside Zone B. Such an effect has been identified in the case of welfare migration at state borders in the US (McKinnish, 2005; Mckinnish, 2007). It is important to test for this type of effect because localised migration could bias policy estimates upwards and may be inconsistent with the goals of policy makers. We test directly for the presence of localised migration by studying how the population growth rates vary with the distance to the border. The details of this exercise are presented in the Results section.

\section{Results}

\subsection{Diff-in-Diff Results}

The results of the D-in-D models are presented in Tables 4 and 5. The first panel of Table 4 presents the results of the multi-period D-in-D model given in equation (1), and the second panel includes the results after controlling for the interaction between covariates and time fixed effects. Table 5 presents estimation results when locality fixed effects are controlled for. The issue of autocorrelation in D-in-D models has been highlighted by Bertrand et al (2004). In the present study, spatial dependence may also affect inference. In all tables, we therefore present two sets of 
standard errors; robust standard errors clustered by locality and Conley (1999) Spatial HAC standard errors, which account for spatial and temporal autocorrelation ${ }^{18}$. The estimated growth effect of the ZTO for the period 1933-1947 is positive and statistically significant in all specifications. The coefficients are all economically large, with the point estimate for our $100 \mathrm{~km}$ sample (the most conservative estimate) implying an annualised population growth premium of approximately 5 to 8 percentage points for the two initial years of the policy, depending on the specification. The pattern of estimated policy effects across different distance buffers is not monotonic, with the largest estimate obtained in the $200 \mathrm{~km}$ sample. The coefficient on the gender ratio (not shown in the tables) is not statistically significant. Looking at the 1947-54 and 1954-61 periods we in general do not see consistent evidence of a policy effect. The estimates for the 1947-54 periods are positive but typically significant only for the largest distance buffer, while the estimates for the 1954-61 are never significant. Overall, the results of the D-in-D analysis suggest that the ZTO had a relatively large but temporary effect on the population growth rates in the Zone B localities.

\subsection{Spatial RD Results}

The preceding D-in-D results rest on the assumption that selection into receiving the ZTO could have occurred only on the time invariant characteristics. We now implement an alternative, and arguably a more credible, identification strategy that takes advantage of the geographical nature of the ZTO policy by estimating a spatial RD model that uses precise geographical coordinates of the localities as a two dimensional running variable. Similarly to the D-in-D specification, the spatial RD models are estimated on four different samples, gradually decreasing the bandwidth around the Zone B boundary. Throughout we present results for the

\footnotetext{
${ }^{18}$ The standard errors were computed using the Stata code used in Hsiang (2010).
} 
basic spatial RD specification without controlling for the observed covariates. The estimation results of spatial RD models with covariates are presented in the Appendix (Tables A1-A4). We also present results for the $100 \mathrm{~km}$ buffer using nearest neighbour matching and investigate the contribution of more geographically proximate localities to the overall estimated policy effect as a model validity exercise.

The spatial RD results for the post policy time periods (Table 6) are consistent with those obtained from the D-in-D specification. The estimated effect of the ZTO on the 1933-47 population growth rate is positive and statistically significant in most specifications, and does not seem to depend on the functional form of the running variable. While the results using a linear control function are less precise than with a quadratic control function, the point estimates are close to those obtained in the D-in-D specification and further are always statistically significant when covariates are included (Table A2). The estimates obtained using the $100 \mathrm{~km}$ bandwidths imply a growth premium of around 5 percentage points in the two years following the introduction of the policy. These estimates match closely point estimates obtained in the D-in-D model. The point estimates of the policy effect in the 1947-54 period are typically around half of those from the 1933-47 period, while the estimates from the 1954-61 period are even smaller in magnitude and sometimes negative. In both of these cases the treatment effects are not precisely estimated.

The matching estimator results (Table 7) are consistent with OLS. The point estimates imply a growth premium of around 6 percentage points in the two years following the introduction of the ZTO and a statistically insignificant policy effect in all other periods. Because matches that are geographically closer are likely to be more reliable, it is useful to examine the estimated treatment effect for the subset of localities with matches within a certain distance of each other. 
If this effect differs markedly from the overall policy effect it would bring into question both the OLS and matching estimator results. We find that for the 1933-47 period, the average policy effect for matches within $150 \mathrm{~km}$ is 0.14 , which is close to the overall estimate ${ }^{19}$. We also find consistent results between the proximate subsample and the overall policy effect for other periods.

Overall, the spatial RD results back up the conclusions derived from the D-in-D models. They point to a relatively large positive effect immediately after the introduction of the policy, and much smaller or even zero growth premium in later years.

\subsection{Spatial RD: Testing for localised migration}

The fact that the policy effect does not increase as the sample bandwidths are reduced in the D-in-D and spatial RD models indicates that localised migration is not driving the results for the 1945-47 period. To test directly whether localised migration could have contributed to the reduced population decline, simple linear regression models were separately estimated for the treatment and control localities with indicator variables for each $50 \mathrm{~km}$ group. In these models we also included controls for geographical coordinates to account for the fact that localities that are the same distance to the border are not necessarily spatially proximate. The results are presented in Table 8 . While the coefficient on the $50-100 \mathrm{~km}$ indicator is positive in the control sample, this indicator is also positive in the treatment sample, which does not support localised migration. Moreover, none of the group indicators are statistically significant. Based on this evidence, localized migration does not appear to have been the sole or main driver of the higher growth rates in the Zone B localities in the post-policy period.

\footnotetext{
${ }^{19} 50 \%$ of matches were under $150 \mathrm{~km}$. As we have argued previously, such distances are not extreme in our context given the severe rurality of our sample.
} 


\section{4: Male population changes}

One concern with finding a policy effect for the $1945-47$ period is that it coincides with the end of World War II. Soldier enlistment and resettlement after the war is likely to have affected population growth heterogeneously across the country. To assess whether this is likely to influence our findings we consider changes in the proportion of males in our treatment and control groups. First, note that in 1933 localities inside and outside Zone B had statistically indistinguishable male population shares (Table 2).

If resettlement or enlistment patterns explain the difference in population growth across the boundary we would expect the male population share to increase between 1933-47 in Zone B localities relative to control. To test this we replaced population growth with the change in proportion males as the dependent variable and re-estimated the spatial RD model for the 1933-47 period. This is an imperfect approach since the male population share may have increased in Zone B localities as a direct consequence of the ZTO. Since we find no statistically significant difference in the change in male population share (Table A5), this is inconsequential. We also searched historical records and found no evidence of a relationship between soldier resettlement schemes and the ZTO zones. Overall we have no evidence to suggest soldier enlistment or resettlement confounds our results.

\section{5: Sensitivity}

In this subsection we discuss the sensitivity of our results to certain sample restrictions. For brevity, additional estimation results referred to here are not presented in the paper but are available on request. One possible concern is that a $100 \mathrm{~km}$ bandwidth is too large for sample homogeneity. We have argued that in the context of our study, where observations in both 
control and treatment groups are small, remote or rural localities, such distances are not unreasonable. Nevertheless, as a robustness check we re-estimated our models on samples restricted to $50 \mathrm{~km}$ of the policy boundary. The sample sizes for each period in this case varied between 31-36 observations and for this reason we were concerned that we could not adequately control for the relationship between space and population growth in the context of our spatial RD model (hence these estimations are not presented as part of our main results). The results for this restricted sample are in fact consistent with those in the paper. D-in-D specifications estimate a statistically significant growth premium of 10-12 percentage points per year between 1945-47, with no growth difference in subsequent periods. Similar estimates are obtained for the spatial RD model.

Our results are somewhat sensitive to excluding localities within $30 \mathrm{~km}$ of the coast in QLD. This restriction is motivated by the fact that we observe large clusters of localities in this region belonging predominately to three major settlements: Townsville and McKay in Zone B and Rockhampton in our control sample. Small deviations in the growth trajectories of any of these areas could drive our results and cause a spurious association between the ZTO and population growth. Since these areas are clearly different to the other observations in our sample (which are typically inland and sparsely populated) our preferred approach is to exclude them from the analysis so that we can focus on a more homogenous group. Including these observations still results in positive coefficient estimates for the ZTO in the period 1933-47 but these estimates are generally statistically insignificant. It also results in some evidence of a positive policy effect in 1954-61, although this evidence is weaker for the D-in-D models. Finally, we note that removing the restriction that involved deleting localities that experienced a population change greater than 
three standard deviations from the mean during any period does not materially affects our estimates or conclusions.

\section{Conclusion}

In this paper we have estimated the effect of the ZTO policy on population growth in regional Australia in the post-World War II period. The results of the D-in-D and spatial RD models point to a positive policy effect in the localities that received the ZTO in 1945 . In particular, Zone B localities experienced lower population decline rates immediately after the policy introduction. We do not find evidence that this is driven by localised migration (people located close to the policy boundary moving to the other side), perhaps suggesting the existence of relatively high moving costs or insufficient incentives to migrate. The effect was relatively short lived - the population growth premium was much lower (or zero according to some specifications) in treated localities between the periods 1947-54 and 1954-61. Consequently, the ZTO appears to have increased population levels (due to the one-off increase in growth) but not the longer-term trend. Since levels and growth are both important for policy makers, it is helpful to make this distinction.

Our results are consistent across all bandwidths (distance from the border) that we considered, and are robust to different functional form specifications of the running variable in the RD setting. The falsification tests conducted using the spatial RD design support the assumption that there were no differences in the growth rates between the treatment and control groups in the 1921-33 period, lending more credence to our identification strategy. It must also be mentioned that due to data limitations, we have focused only on the effect of the ZTO in the 
Zone B area (see figure 1). The payment to Zone A regions was considerably larger and it is possible the policy effect was more pronounced there. We are not able to evaluate the policy effect in Zone A because it is too sparsely populated to make locality level analysis practical.

We believe our results provide a useful empirical insight into the power of government to influence rural population dynamics and conversely to provide welfare support without influencing population. Nevertheless, it is critical to interpret these results within the context they are studied and to take note of their limitations. Importantly, the ZTO was introduced during a period of population decline and it is unclear whether it would have had the same effect on population growth if population had not been declining. Since governments are likely to be most interested in ZTO-like policies during periods of population decline, our setting may actually be the most insightful. One limitation of our data is that they did not allow us to test for the effect of the ZTO on land and housing prices. According to spatial equilibrium theory (Rosen, 1976; Roback, 1982), a population growth premium cannot persist in the long run because migration into the areas with lower income taxes will tend to increase the prices of non-tradable factors, stemming any future population growth. This mechanism could potentially explain why we fail to observe a growth premium in later periods and should be borne in mind when considering policy implications and future research. In particular, price responses would be critical in calculating the welfare effects on the ZTO. 


\section{References}

Abadie A, Imbens GW (2011) Bias-Corrected Estimators for Average Treatment Effects. Journal of Business \& Economic Statistics, 29: 1-11

Australians Bureau of Statistics (1947) Official Year Book of the Commonwealth of Australia No. 37 - 1946 and 1947. Canberra, ACT

Behaghel L, Lorenceau A, Quantin S (2015) Replacing churches and mason lodges? Tax exemptions and rural development. Journal of Public Economics 125: 1-15

Bertrand M, Duflo E, Mullainathan S, (2004) "How Much Should We Trust Differences-inDifferences Estimates?. Quarterly Journal of Economics 119: 249-275

Blomquist GC, Berger MC, Hoehn JP (1988) New Estimates of Quality of Life in Urban Areas. American Economic Review 78: 89-107

Busso M, Gregory J, Kline P (2013) Assessing the Incidence and Efficiency of a Prominent Place Based Policy. American Economic Review 103: 897-947

Chifley B (1945) Second Reading speech: Income Tax Assessment Bill 1945

Conley TG (1999) GMM Estimation with Cross Sectional Dependence. Journal of Econometrics 92: $1-45$

Connolly E, Lewis C (2010) Structural Change in the Australian Economy. Bulletin September: $1-9$

Dell M (2010) The Persistent Effects of Peru’s Mining Mita. Econometrica 78: 1863-1903

Deller SCT, Tsung-Hsiu T, Marcouiller DW, English DBK (2001) The Role of Amenities and Quality of Life in Rural Economic Growth. American Journal of Agricultural Economics 83: 352-365

Freedman M (2013) Targeted business incentives and local labor markets. Journal of Human Resources, 48: 311-344

Glaeser EL, Gottlieb, JD (2008) The Economics of Place-Making Policies. Brookings Papers on Economic Activity. Spring (2008): 155-239

Gobillon L, Magnac T, Selod H (2012) Do unemployed workers benefit from enterprise zones? The French experience. Journal of Public Economics 96: 881-892.

Graves PE (1980) Migration and Climate. Journal of Regional Science 20: 227-237 
Ham JC, Swenson C, İmrohoroğlu A, Song H (2011) Government programs can improve local labor markets: Evidence from State Enterprise Zones, Federal Empowerment Zones and Federal Enterprise Community. Journal of Public Economics 95: 779-797

Hanson A (2009) Local employment, poverty, and property value effects of geographicallytargeted tax incentives: An instrumental variables approach. Regional Science and Urban Economics 39: 721-731

Hoehn JP, Berger MC, Blomquist GC (1987) A Hedonic Model of Interregional Wages, Rents, and Amenity Values. Journal of Regional Science 27: 605-620

Hsiang SM (2010) Temperatures and cyclones strongly associated with economic production in the Caribbean and Central America. Proceedings of the National Academy of Science 107: $15367-15372$

Irwin EG, Isserman AM, Kilkenny M, Partridge MD (2010) A Century of Research on Rural Development and Regional Issues. American Journal of Agricultural Economics 92: 522-553

Jofre-Monseny J (2014) The effects of unemployment protection on migration in lagging regions. Journal of Urban Economics 83: 73-86

Kline P, Moretti E (2014) Local Economic Development, Agglomeration Economies, and the Big Push: 100 Years of Evidence from the Tennessee Valley Authority. Quarterly Journal of Economics 129: 275-331

Lee DS, Lemieux T (2010) Regression Discontinuity Designs in Economics. Journal of Economic Literature 48: 281-355

McKinnish T (2005) Importing the Poor. Journal of Human Resources 15: 57-76

McKinnish T (2007) Welfare-induced migration at state borders: New evidence from micro-data. Journal of Public Economics 91: 437-450

Neumark D, Kolko J (2010) Do enterprise zones create jobs? Evidence from California's enterprise zone program. Journal of Urban Economics 68: 1-19

Neumark D, Simpson H (2014) Place-based Policies. NBER Working Paper 20049

Reynolds CL, Rohlin S (2015) The Effects of Location-based Tax Policies on the Distribution of Household Income: Evidence from the Federal Empowerment Zone Program. Journal of Urban Economics 88: 1-15

Roback J (1982) Wages, Rents, and the Quality of Life. Journal of Political Economy 90: 12571278 
Rosen S (1979) Wage-Based Indexes of Urban Quality of Life. In: Mieszkowski P, Straszheim M (eds) Current Issues in Urban Economics. Johns Hopkins University Press, Baltimore

Taylor JE, Martin PL (2001) Human capital: Migration and rural population change. In: Gardner BL, Rausser GC (eds) Handbook of Agricultural Economics. Elsevier 
Figure 1: Zone Map (Scale 1:25,000,000)*

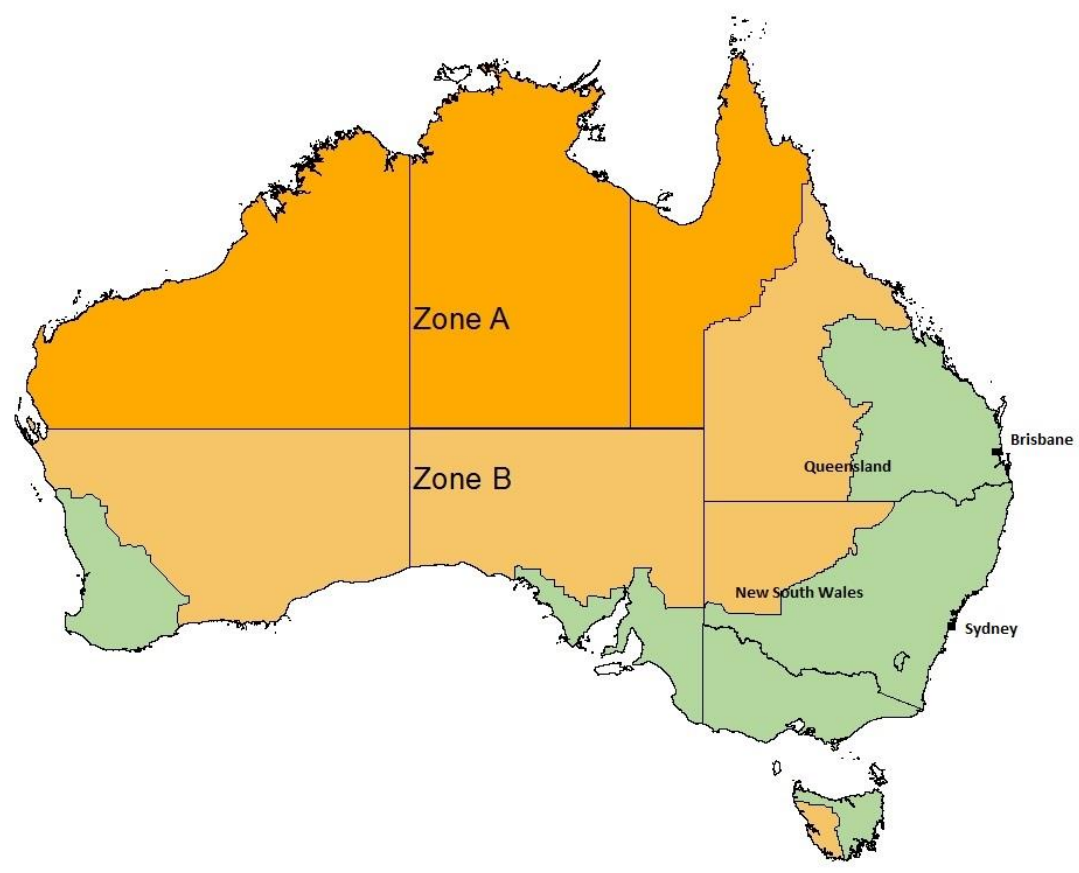

Note: *The green colour represents the region outside of Zones A and B. 
Figure 2: Base value of the ZTO for Zone B residents 1945-1976

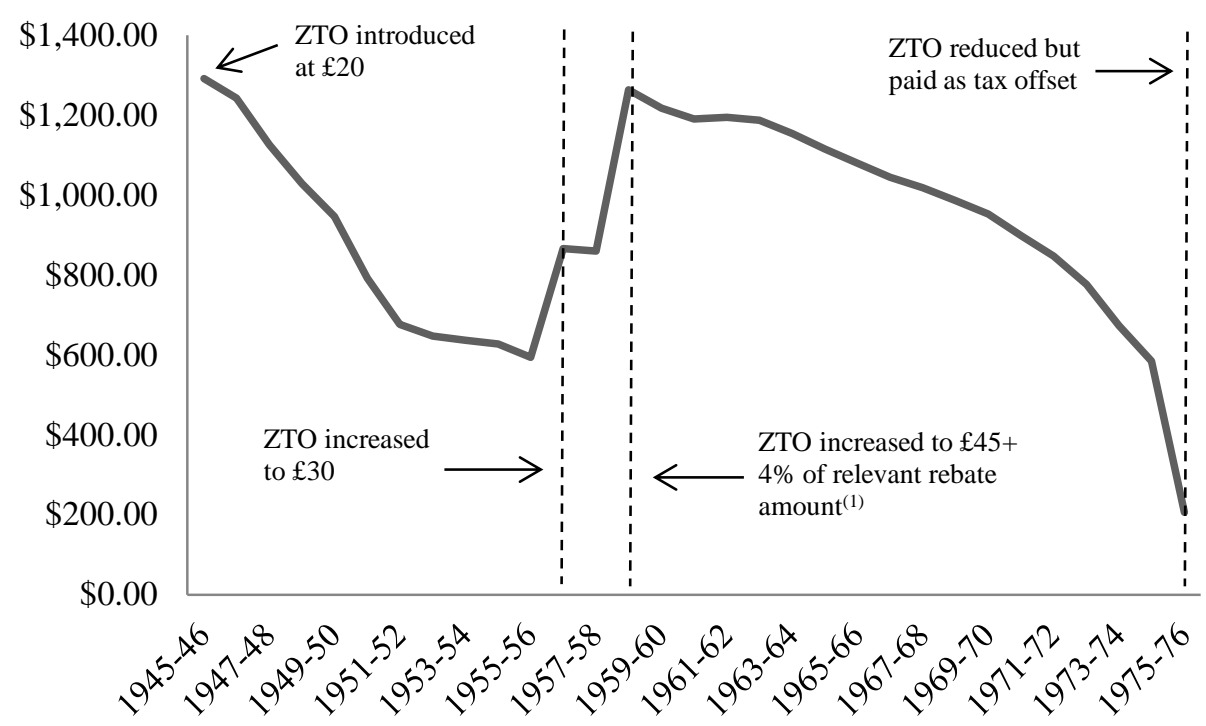

Note: The value of the ZTO is expressed in 2013 dollars. The Reserve Bank of Australia's inflation calculators were used to generate the figures. In all financial years prior to 1975-76, the ZTO was available as a deduction to reduce the recipient's taxable income. From 1 July 1975 the ZTO was paid as a fixed reduction in tax payable. (1) Relevant rebate amount refers to the value of certain other dependency tax offsets that the person is entitled to or would be entitled to had those tax offsets not previously been repealed. The practical effect is that the ZTO is higher for people who maintain a dependent, including a housekeeper, spouse or child. 
Figure 3: Estimation Sample, $250 \mathrm{~km}$ buffer (Scale 1:20,000,000)*

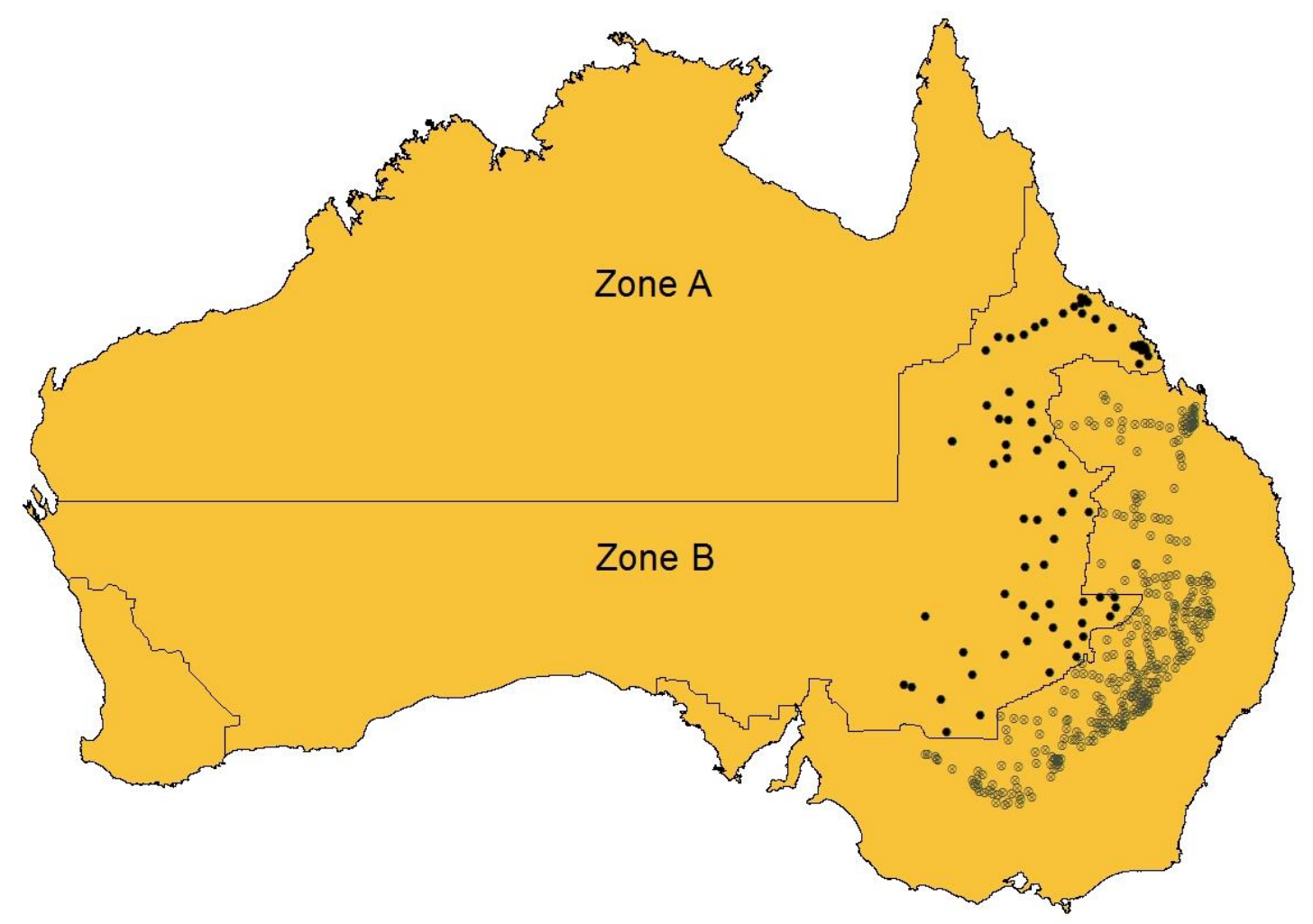

Note: *Treatment localities are denoted by dark circles and control localities are denoted by light circles. 
Figure 4: Population growth in localities 1933-1961
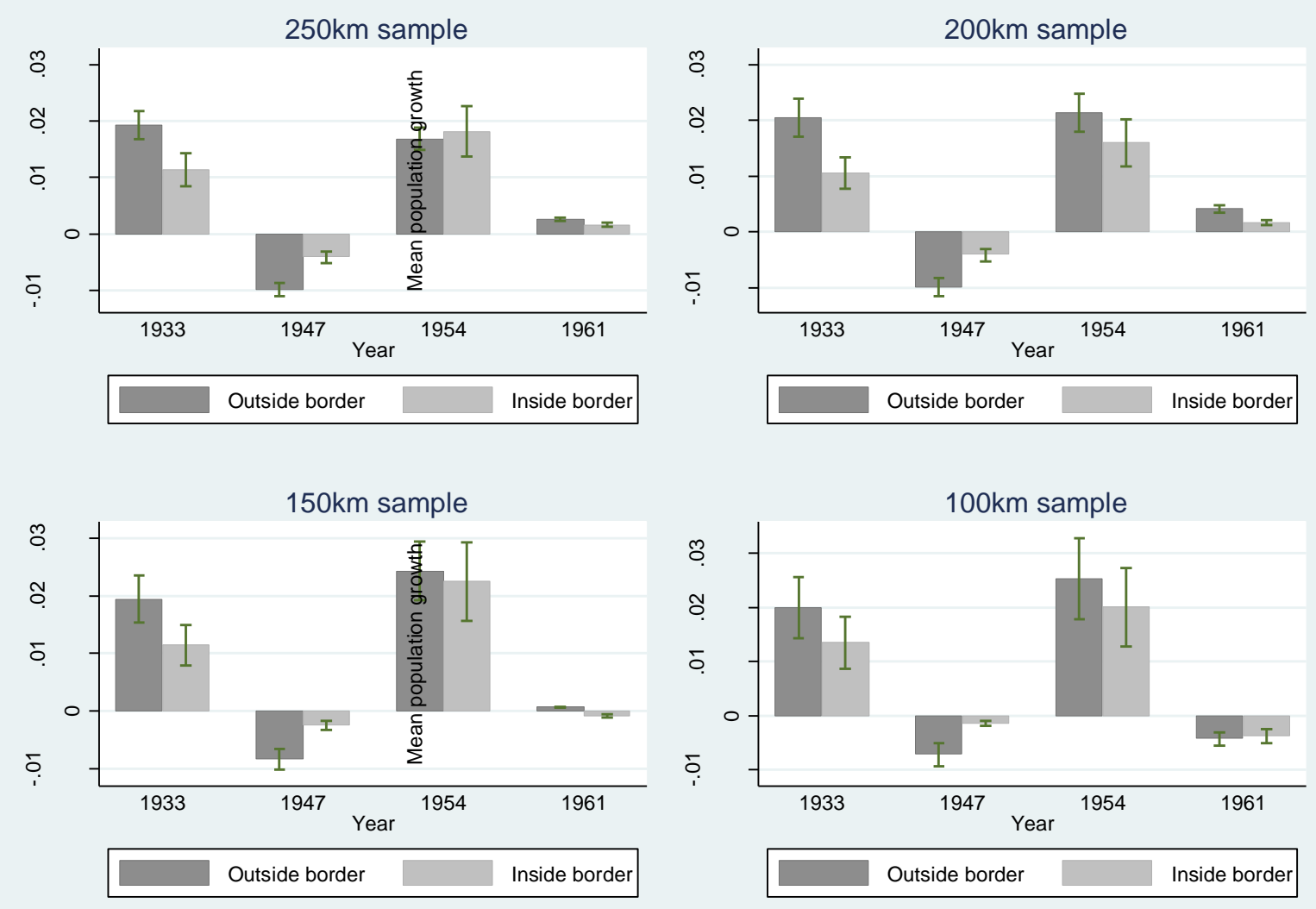

Note: Population growth (the percentage change in population between censuses) has been annualised for each period. The base year for 1933 is the 1921 census. $95 \%$ confidence intervals shown. 
Table 1: Sample counts by distance to border 1933

\begin{tabular}{lcccccc}
\hline $\begin{array}{l}\text { Distance to } \\
\text { border }(\mathbf{k m})\end{array}$ & Frequency & Percentage & $\begin{array}{c}\text { Cumulative } \\
\text { percentage }\end{array}$ & Frequency & $\begin{array}{c}\text { Percentage } \\
\text { Cumulative } \\
\text { percentage }\end{array}$ \\
\hline & & Inside Zone B & & & Outside Zone B \\
$0-25$ & 9 & 13.04 & 13.04 & 10 & 3.53 & 3.53 \\
$26-50$ & 5 & 7.25 & 20.29 & 12 & 4.24 & 7.77 \\
$51-75$ & 7 & 10.14 & 30.43 & 14 & 4.95 & 12.72 \\
$76-100$ & 11 & 15.94 & 46.38 & 13 & 4.59 & 17.31 \\
$101-125$ & 4 & 5.8 & 52.17 & 20 & 24.07 & 24.38 \\
$126-150$ & 7 & 10.14 & 62.32 & 24 & 8.48 & 32.86 \\
$151-175$ & 12 & 17.39 & 79.71 & 25 & 8.83 & 41.7 \\
$176-200$ & 6 & 8.7 & 88.41 & 42 & 14.84 & 56.54 \\
$201-225$ & 3 & 4.35 & 92.75 & 49 & 17.31 & 73.85 \\
$226-250$ & 5 & 7.25 & 100 & 74 & 26.15 & 100 \\
\hline
\end{tabular}

Total

69

283 
Table 2: Descriptive statistics 1933

\begin{tabular}{|c|c|c|c|c|c|c|}
\hline \multirow{2}{*}{$\begin{array}{l}\text { Variable } \\
\text { Population }\end{array}$} & \multicolumn{2}{|c|}{ Zone B } & \multicolumn{2}{|c|}{ Control } & \multicolumn{2}{|l|}{ Difference } \\
\hline & Mean & Std. deviation & Mean & Std. deviation & Mean & Sample size \\
\hline $250 \mathrm{~km}$ & 1030.435 & 3370.752 & 612.717 & 1072.850 & $417.718 *$ & $69(283)$ \\
\hline $200 \mathrm{~km}$ & 1114.852 & 3572.284 & 654.638 & 1104.834 & 460.215 & $61(160)$ \\
\hline $150 \mathrm{~km}$ & 1219.295 & 4060.235 & 645.226 & 903.145 & 574.069 & $44(93)$ \\
\hline $100 \mathrm{~km}$ & 469.750 & 563.722 & 527.551 & 576.683 & -57.801 & $32(49)$ \\
\hline \multicolumn{7}{|l|}{$\%$ Males } \\
\hline $250 \mathrm{~km}$ & 0.568 & 0.069 & 0.573 & 0.058 & -0.006 & $69(283)$ \\
\hline $200 \mathrm{~km}$ & 0.562 & 0.064 & 0.577 & 0.064 & -0.015 & $61(160)$ \\
\hline $150 \mathrm{~km}$ & 0.566 & 0.048 & 0.575 & 0.070 & -0.010 & $44(93)$ \\
\hline $100 \mathrm{~km}$ & 0.565 & 0.051 & 0.580 & 0.080 & -0.015 & $32(49)$ \\
\hline \multicolumn{7}{|l|}{$\%$ Working } \\
\hline $250 \mathrm{~km}$ & 0.475 & 0.054 & 0.467 & 0.036 & 0.008 & $63(253)$ \\
\hline $200 \mathrm{~km}$ & 0.473 & 0.052 & 0.471 & 0.037 & 0.002 & $54(145)$ \\
\hline $150 \mathrm{~km}$ & 0.461 & 0.048 & 0.477 & 0.037 & -0.017 & $37(80)$ \\
\hline $100 \mathrm{~km}$ & 0.450 & 0.032 & 0.488 & 0.038 & -0.038 & $27(41)$ \\
\hline \multicolumn{7}{|c|}{$\%$ Agriculture } \\
\hline $250 \mathrm{~km}$ & 0.199 & 0.111 & 0.232 & 0.090 & -0.033 & $63(253)$ \\
\hline $200 \mathrm{~km}$ & 0.201 & 0.109 & 0.232 & 0.091 & -0.031 & $54(145)$ \\
\hline $150 \mathrm{~km}$ & 0.205 & 0.108 & 0.229 & 0.099 & -0.024 & $37(80)$ \\
\hline $100 \mathrm{~km}$ & 0.216 & 0.097 & 0.236 & 0.099 & -0.020 & $27(41)$ \\
\hline \multicolumn{7}{|l|}{$\%$ Mining } \\
\hline $250 \mathrm{~km}$ & 0.015 & 0.036 & 0.011 & 0.023 & 0.005 & $63(253)$ \\
\hline $200 \mathrm{~km}$ & 0.016 & 0.038 & 0.006 & 0.018 & $0.010 *$ & $54(145)$ \\
\hline $150 \mathrm{~km}$ & 0.012 & 0.037 & 0.005 & 0.013 & 0.008 & $37(80)$ \\
\hline $100 \mathrm{~km}$ & 0.002 & 0.005 & 0.001 & 0.002 & 0.001 & $27(41)$ \\
\hline \multicolumn{7}{|c|}{$\%$ Manufacturing } \\
\hline $250 \mathrm{~km}$ & 0.030 & 0.027 & 0.013 & 0.008 & $0.018 * * *$ & $63(253)$ \\
\hline $200 \mathrm{~km}$ & 0.031 & 0.026 & 0.013 & 0.008 & $0.018 * * *$ & $54(145)$ \\
\hline $150 \mathrm{~km}$ & 0.030 & 0.019 & 0.013 & 0.008 & $0.017 * * *$ & $37(80)$ \\
\hline $100 \mathrm{~km}$ & 0.033 & 0.020 & 0.013 & 0.008 & $0.020 * * *$ & $27(41)$ \\
\hline
\end{tabular}

Note: a Sample size outside parenthesis is for ZTO localities and in parenthesis is control group. Standard errors clustered at 1933 LGA levels used to compare LGA level variables. $* \mathrm{p}<0.1, * * \mathrm{p}<0.05, * * * \mathrm{p}<0.01$. 


\section{Table 3: Comparison of characteristics at Zone B boundary}

Mean

\begin{tabular}{lccc} 
Variable & Zone B & Control & Difference (p-value) \\
\hline Elevation $^{\mathrm{a}}$ & 256.24 & 270.55 & $-14.31(0.460)$ \\
Average rainfall 1946-1955 $^{\mathrm{b}}$ & 542.45 & 543.40 & $-0.95(0.964)$ \\
\hline $\mathrm{n}$ & 165 & 169 & 334
\end{tabular}

Note: Data are from centroid points of 20x20 km grids that were overlayed across the sample space. All observations are within $25 \mathrm{~km}$ of the Zone B boundary. ${ }^{\text {a }}$ Elevation at each point is taken from Geoscience Australia 1 second SRTM Derived Digital Elevation Model Version 1.0 (ㄷ Commonwealth of Australia (Geoscience Australia) 2011). This is measured in meters ${ }^{\mathrm{b}}$ Data on average rainfall over the period 1946 to 1955 are from the Australian Bureau of Meteorology and available at:

http://www.bom.gov.au/climate/averages/climatology/gridded-data-info/metadata/md_hires_rain_1900+.shtml This is measured in $\mathrm{mm} . * \mathrm{p}<0.1, * * \mathrm{p}<0.05, * * * \mathrm{p}<0.01$. 
Table 4: Multi-period DD model (1921-1961)

\begin{tabular}{|c|c|c|c|c|}
\hline \multirow[b]{2}{*}{ Variable } & \multicolumn{4}{|c|}{ Equation 1} \\
\hline & $250 \mathrm{~km}$ & $200 \mathrm{~km}$ & $150 \mathrm{~km}$ & $100 \mathrm{~km}$ \\
\hline ZTO dummy*1933-47 & $\begin{array}{l}0.173 \\
(0.058)^{* * *} \\
{[0.071]^{* *}}\end{array}$ & $\begin{array}{l}0.200 \\
(0.065)^{* * *} \\
{[0.072]^{* * *}}\end{array}$ & $\begin{array}{l}0.170 \\
(0.072)^{* *} \\
{[0.063]^{* * *}}\end{array}$ & $\begin{array}{l}0.154 \\
(0.082)^{*} \\
{[0.050]^{* * *}}\end{array}$ \\
\hline ZTO dummy*1947-54 & $\begin{array}{l}0.114 \\
(0.048)^{* *} \\
{[0.069]}\end{array}$ & $\begin{array}{l}0.097 \\
(0.056)^{*} \\
{[0.071]}\end{array}$ & $\begin{array}{l}0.086 \\
(0.066) \\
{[0.072]}\end{array}$ & $\begin{array}{l}0.046 \\
(0.084) \\
{[0.057]}\end{array}$ \\
\hline ZTO dummy*1954-61 & $\begin{array}{l}0.094 \\
(0.051)^{*} \\
{[0.062]}\end{array}$ & $\begin{array}{l}0.113 \\
(0.057)^{* *} \\
{[0.065]^{*}}\end{array}$ & $\begin{array}{l}0.086 \\
(0.068) \\
{[0.069]}\end{array}$ & $\begin{array}{l}0.084 \\
(0.084) \\
{[0.059]}\end{array}$ \\
\hline $\begin{array}{l}\text { Controls interacted with time } \\
\text { indicators? }\end{array}$ & No & No & No & No \\
\hline \multirow[t]{2}{*}{$\mathrm{n}$} & $\begin{array}{l}0.22 \\
1,318\end{array}$ & $\begin{array}{l}0.23 \\
822\end{array}$ & $\begin{array}{l}0.23 \\
521\end{array}$ & $\begin{array}{l}0.25 \\
305\end{array}$ \\
\hline & \multicolumn{4}{|c|}{ Equation 1 with time interactions } \\
\hline ZTO dummy*1933-47 & $\begin{array}{l}0.154 \\
(0.054)^{* * *} \\
{[0.068]^{* *}}\end{array}$ & $\begin{array}{l}0.179 \\
(0.063)^{* * *} \\
{[0.069]^{* * *}}\end{array}$ & $\begin{array}{l}0.159 \\
(0.072)^{* *} \\
{[0.061]^{* * *}}\end{array}$ & $\begin{array}{l}0.125 \\
(0.082) \\
{[0.049]^{* *}}\end{array}$ \\
\hline ZTO dummy*1947-54 & $\begin{array}{l}0.106 \\
(0.049)^{* *} \\
{[0.066]}\end{array}$ & $\begin{array}{l}0.087 \\
(0.055) \\
{[0.068]}\end{array}$ & $\begin{array}{l}0.079 \\
(0.067) \\
{[0.072]}\end{array}$ & $\begin{array}{l}0.040 \\
(0.083) \\
{[0.060]}\end{array}$ \\
\hline ZTO dummy*1954-61 & $\begin{array}{l}0.073 \\
(0.048) \\
{[0.059]}\end{array}$ & $\begin{array}{l}0.099 \\
(0.055)^{*} \\
{[0.061]}\end{array}$ & $\begin{array}{l}0.075 \\
(0.067) \\
{[0.062]}\end{array}$ & $\begin{array}{l}0.073 \\
(0.081) \\
{[0.052]}\end{array}$ \\
\hline $\begin{array}{l}\text { Controls interacted with time } \\
\text { indicators? }\end{array}$ & Yes & Yes & Yes & Yes \\
\hline $\begin{array}{l}\mathrm{R} 2 \\
\mathrm{n}\end{array}$ & $\begin{array}{l}0.26 \\
1,318\end{array}$ & $\begin{array}{l}0.26 \\
822\end{array}$ & $\begin{array}{l}0.26 \\
521\end{array}$ & $\begin{array}{l}0.30 \\
305\end{array}$ \\
\hline
\end{tabular}

Note: Robust standard errors clustered at localities reported in parenthesis. Conley standard errors are in brackets. These assume no spatial dependence beyond $100 \mathrm{~km}$ and one lag for error dependence. Dependent variable is change in log population across the periods 1921-33, 1933-47, 1947-54 and 1954-61. Controls are a cubic in log population and percentage of males in the base year as well as year dummies for 1933, 1947 and 1954. ${ }^{*} \mathrm{p}<0.1, * * \mathrm{p}<0.05, * * * \mathrm{p}<0.01$. 
Table 5: FE model (1921-1961)

\begin{tabular}{|c|c|c|c|c|}
\hline \multirow[b]{2}{*}{ Variable } & \multicolumn{4}{|c|}{ Equation 3 with locality fixed effects } \\
\hline & $250 \mathrm{~km}$ & $200 \mathrm{~km}$ & $150 \mathrm{~km}$ & $100 \mathrm{~km}$ \\
\hline ZTO dummy*1933-47 & $\begin{array}{l}0.111 \\
(0.038) * * * \\
{[0.044]^{* *}}\end{array}$ & $\begin{array}{l}0.131 \\
(0.043)^{* * *} \\
{[0.043]^{* * *}}\end{array}$ & $\begin{array}{l}0.119 \\
(0.046)^{* *} \\
{[0.046]^{* * *}}\end{array}$ & $\begin{array}{l}0.122 \\
(0.052)^{* *} \\
{[0.052]^{* *}}\end{array}$ \\
\hline ZTO dummy*1947-54 & $\begin{array}{l}0.104 \\
(0.040)^{* * *} \\
{[0.042]^{* *}}\end{array}$ & $\begin{array}{l}0.075 \\
(0.045)^{*} \\
{[0.044]^{*}}\end{array}$ & $\begin{array}{l}0.087 \\
(0.047)^{*} \\
{[0.042]^{* *}}\end{array}$ & $\begin{array}{l}0.069 \\
(0.057) \\
{[0.043]}\end{array}$ \\
\hline ZTO dummy*1954-61 & $\begin{array}{l}0.089 \\
(0.041)^{* *} \\
{[0.045]^{* *}}\end{array}$ & $\begin{array}{l}0.057 \\
(0.046) \\
{[0.046]}\end{array}$ & $\begin{array}{l}0.062 \\
(0.053) \\
{[0.051]}\end{array}$ & $\begin{array}{l}0.071 \\
(0.069) \\
{[0.060]}\end{array}$ \\
\hline $\begin{array}{l}\text { Controls interacted with time } \\
\text { indicators? }\end{array}$ & No & No & No & No \\
\hline $\mathrm{R} 2$ & 0.63 & 0.62 & 0.64 & 0.64 \\
\hline \multirow[t]{2}{*}{$\mathrm{n}$} & 1,318 & 822 & 521 & 305 \\
\hline & \multicolumn{4}{|c|}{ Equation 3 with locality fixed effects and time interactions } \\
\hline ZTO dummy*1933-47 & $\begin{array}{l}0.086 \\
(0.034)^{* *} \\
{[0.042]^{* *}}\end{array}$ & $\begin{array}{l}0.105 \\
(0.040)^{* * *} \\
{[0.041]^{* *}}\end{array}$ & $\begin{array}{l}0.108 \\
(0.044)^{* *} \\
{[0.045]^{* *}}\end{array}$ & $\begin{array}{l}0.101 \\
(0.052)^{*} \\
{[0.045]^{* *}}\end{array}$ \\
\hline ZTO dummy*1947-54 & $\begin{array}{l}0.081 \\
(0.040)^{* *} \\
{[0.043]^{*}}\end{array}$ & $\begin{array}{l}0.056 \\
(0.045) \\
{[0.044]}\end{array}$ & $\begin{array}{l}0.078 \\
(0.050) \\
{[0.044]^{*}}\end{array}$ & $\begin{array}{l}0.054 \\
(0.057) \\
{[0.041]}\end{array}$ \\
\hline ZTO dummy*1954-61 & $\begin{array}{l}0.046 \\
(0.038) \\
{[0.043]}\end{array}$ & $\begin{array}{l}0.034 \\
(0.043) \\
0.044]\end{array}$ & $\begin{array}{l}0.055 \\
(0.053) \\
{[0.047]}\end{array}$ & $\begin{array}{l}0.056 \\
(0.067) \\
{[0.047]}\end{array}$ \\
\hline $\begin{array}{l}\text { Controls interacted with time } \\
\text { indicators? }\end{array}$ & Yes & Yes & Yes & Yes \\
\hline $\mathrm{R} 2$ & 0.66 & 0.65 & 0.66 & 0.67 \\
\hline $\mathrm{n}$ & 1,318 & 822 & 521 & 305 \\
\hline
\end{tabular}

Note: See Table 4. 
Table 6: Spatial RD model

\begin{tabular}{|c|c|c|c|c|c|c|c|c|}
\hline \multirow{3}{*}{$\begin{array}{l}\text { Variable } \\
\text { ZTO dummy }\end{array}$} & \multicolumn{2}{|c|}{$250 \mathrm{~km}$} & \multicolumn{2}{|c|}{$200 \mathrm{~km}$} & \multicolumn{2}{|c|}{$150 \mathrm{~km}$} & \multicolumn{2}{|c|}{$100 \mathrm{~km}$} \\
\hline & \multicolumn{7}{|c|}{ Dependent variable $=$ population growth $1921-33$} & \multirow[b]{2}{*}{$\begin{array}{l}-0.042 \\
(0.091) \\
\end{array}$} \\
\hline & $\begin{array}{l}0.058 \\
(0.062)\end{array}$ & $\begin{array}{l}0.056 \\
(0.071)\end{array}$ & $\begin{array}{l}0.075 \\
(0.064)\end{array}$ & $\begin{array}{l}0.045 \\
(0.076)\end{array}$ & $\begin{array}{l}0.049 \\
(0.072)\end{array}$ & $\begin{array}{l}0.028 \\
(0.088)\end{array}$ & $\begin{array}{l}-0.023 \\
(0.072) \\
\end{array}$ & \\
\hline $\begin{array}{l}\text { Control } \\
\text { function }\end{array}$ & Linear & Quadratic & Linear & Quadratic & Linear & Quadratic & Linear & Quadratic \\
\hline $\mathrm{R}^{2}$ & 0.10 & 0.10 & 0.13 & 0.14 & 0.14 & 0.16 & 0.10 & 0.21 \\
\hline $\mathrm{n}$ & 296 & 296 & 194 & 194 & 127 & 127 & 78 & 78 \\
\hline \multicolumn{9}{|c|}{ Dependent variable = population growth 1933-47 } \\
\hline ZTO dummy & $\begin{array}{l}0.051 \\
(0.054)\end{array}$ & $\begin{array}{l}0.134 \\
(0.055)^{* *}\end{array}$ & $\begin{array}{l}0.089 \\
(0.054)\end{array}$ & $\begin{array}{l}0.142 \\
(0.058) * *\end{array}$ & $\begin{array}{l}0.081 \\
(0.054)\end{array}$ & $\begin{array}{l}0.152 \\
(0.066)^{* *}\end{array}$ & $\begin{array}{l}0.109 \\
(0.062)^{*}\end{array}$ & $\begin{array}{l}0.115 \\
(0.068)^{*}\end{array}$ \\
\hline $\begin{array}{l}\text { Control } \\
\text { function }\end{array}$ & Linear & Quadratic & Linear & Quadratic & Linear & Quadratic & Linear & Quadratic \\
\hline $\mathrm{R}^{2}$ & 0.06 & 0.11 & 0.04 & 0.11 & 0.03 & 0.07 & 0.05 & 0.07 \\
\hline $\mathrm{n}$ & 324 & 324 & 201 & 201 & 128 & 128 & 74 & 74 \\
\hline \multicolumn{9}{|c|}{ Dependent variable = population growth 1947-54 } \\
\hline ZTO dummy & $\begin{array}{l}0.038 \\
(0.044)\end{array}$ & $\begin{array}{l}0.027 \\
(0.050)\end{array}$ & $\begin{array}{l}0.026 \\
(0.046)\end{array}$ & $\begin{array}{l}0.046 \\
(0.049)\end{array}$ & $\begin{array}{l}0.057 \\
(0.049)\end{array}$ & $\begin{array}{l}0.064 \\
(0.055) \\
\end{array}$ & $\begin{array}{l}0.020 \\
(0.061) \\
\end{array}$ & $\begin{array}{l}0.042 \\
(0.065)\end{array}$ \\
\hline $\begin{array}{l}\text { Control } \\
\text { function }\end{array}$ & Linear & Quadratic & Linear & Quadratic & Linear & Quadratic & Linear & Quadratic \\
\hline $\mathrm{R}^{2}$ & 0.03 & 0.11 & 0.04 & 0.13 & 0.07 & 0.13 & 0.05 & 0.19 \\
\hline $\mathrm{n}$ & 336 & 336 & 205 & 205 & 129 & 129 & 73 & 73 \\
\hline \multicolumn{9}{|c|}{ Dependent variable = population growth $1954-61$} \\
\hline ZTO dummy & $\begin{array}{l}-0.053 \\
(0.041)\end{array}$ & $\begin{array}{l}0.008 \\
(0.040) \\
\end{array}$ & $\begin{array}{l}-0.018 \\
(0.043) \\
\end{array}$ & $\begin{array}{l}0.025 \\
(0.043) \\
\end{array}$ & $\begin{array}{l}-0.026 \\
(0.046) \\
\end{array}$ & $\begin{array}{l}0.034 \\
(0.049) \\
\end{array}$ & $\begin{array}{l}-0.015 \\
(0.053) \\
\end{array}$ & $\begin{array}{l}0.005 \\
(0.056) \\
\end{array}$ \\
\hline $\begin{array}{l}\text { Control } \\
\text { function }\end{array}$ & Linear & Quadratic & Linear & Quadratic & Linear & Quadratic & Linear & Quadratic \\
\hline $\mathrm{R}^{2}$ & 0.02 & 0.05 & 0.01 & 0.04 & 0.01 & 0.13 & 0.04 & 0.15 \\
\hline $\mathrm{n}$ & 362 & 362 & 222 & 222 & 137 & 137 & 80 & 80 \\
\hline
\end{tabular}

Note: Robust standard errors reported in parenthesis. Dependent variable is change in log population across the periods 1921-33, 1933-47, 1947-54 and 1954-61. * $\mathrm{p}<0.1, * * \mathrm{p}<0.05, * * * \mathrm{p}<0.01$. 


\section{Table 7: Matching estimator results}

\begin{tabular}{|c|c|c|c|c|}
\hline & \multicolumn{4}{|c|}{ Dependent variable $=$ population growth for each period } \\
\hline Variable & $1921-33$ & $1933-47$ & $1947-54$ & 1954-61 \\
\hline ZTO dummy & $\begin{array}{l}0.055 \\
(0.087)\end{array}$ & $\begin{array}{l}0.123 \\
(0.062)^{* *}\end{array}$ & $\begin{array}{l}0.023 \\
(0.072)\end{array}$ & $\begin{array}{l}0.044 \\
(0.061)\end{array}$ \\
\hline $\mathrm{n}$ & 78 & 74 & 73 & 80 \\
\hline
\end{tabular}


Table 8: Distance to the border and growth rates, control and treatment samples (1933-47)

\begin{tabular}{|c|c|c|c|c|}
\hline Variable & & & & \\
\hline $50-100 \mathrm{~km}$ & $\begin{array}{c}0.095 \\
(0.076)\end{array}$ & $\begin{array}{c}0.092 \\
(0.087)\end{array}$ & $\begin{array}{c}0.041 \\
(0.127)\end{array}$ & $\begin{array}{l}-0.051 \\
(0.123)\end{array}$ \\
\hline $100-150 \mathrm{~km}$ & $\begin{array}{c}0.013 \\
(0.072)\end{array}$ & $\begin{array}{c}0.032 \\
(0.083)\end{array}$ & $\begin{array}{c}0.094 \\
(0.112)\end{array}$ & $\begin{array}{c}0.102 \\
(0.123)\end{array}$ \\
\hline $150-200 \mathrm{~km}$ & $\begin{array}{l}-0.023 \\
(0.076)\end{array}$ & $\begin{array}{c}0.066 \\
(0.098)\end{array}$ & $\begin{array}{c}0.037 \\
(0.169)\end{array}$ & $\begin{array}{c}0.083 \\
(0.155)\end{array}$ \\
\hline $200-250 \mathrm{~km}$ & $\begin{array}{c}0.033 \\
(0.074) \\
\end{array}$ & $\begin{array}{c}0.162 \\
(0.110) \\
\end{array}$ & $\begin{array}{c}0.122 \\
(0.132) \\
\end{array}$ & $\begin{array}{c}0.012 \\
(0.164) \\
\end{array}$ \\
\hline Control function & Linear & Quadratic & Linear & Quadratic \\
\hline $\begin{array}{l}\mathrm{R}^{2} \\
\mathrm{n}\end{array}$ & $\begin{array}{l}0.09 \\
260\end{array}$ & $\begin{array}{l}0.13 \\
260\end{array}$ & $\begin{array}{c}0.13 \\
64\end{array}$ & $\begin{array}{c}0.23 \\
64\end{array}$ \\
\hline
\end{tabular}

Note: Robust standard errors reported in parenthesis. Dependent variable is change in log population between 1933 and 1947. The variable $50-100 \mathrm{~km}$ is a dummy for whether the locality was between 50 and $100 \mathrm{~km}$ from the Zone B boundary (and so on). $* \mathrm{p}<0.1, * * \mathrm{p}<0.05, * * * \mathrm{p}<0.01$. 
Table A1: Spatial RD model with covariates (1921-1933)

\begin{tabular}{|c|c|c|c|c|c|c|c|c|}
\hline Variable & \multicolumn{2}{|c|}{$250 \mathrm{~km}$} & \multicolumn{2}{|c|}{$200 \mathrm{~km}$} & \multicolumn{2}{|c|}{$150 \mathrm{~km}$} & \multicolumn{2}{|c|}{$100 \mathrm{~km}$} \\
\hline ZTO dummy & $\begin{array}{l}0.023 \\
(0.075)\end{array}$ & $\begin{array}{l}-0.073 \\
(0.093)\end{array}$ & $\begin{array}{l}0.060 \\
(0.086)\end{array}$ & $\begin{array}{l}-0.085 \\
(0.105)\end{array}$ & $\begin{array}{l}0.046 \\
(0.099)\end{array}$ & $\begin{array}{l}-0.115 \\
(0.112)\end{array}$ & $\begin{array}{l}-0.191 \\
(0.128)\end{array}$ & $\begin{array}{l}-0.178 \\
(0.169)\end{array}$ \\
\hline Log population & $\begin{array}{l}-3.086 \\
(0.890)^{* * *}\end{array}$ & $\begin{array}{l}-3.665 \\
(0.867)^{* * *}\end{array}$ & $\begin{array}{l}-1.993 \\
(1.017)^{*}\end{array}$ & $\begin{array}{l}-2.597 \\
(1.175)^{* *}\end{array}$ & $\begin{array}{l}-1.430 \\
(1.451)\end{array}$ & $\begin{array}{l}-3.354 \\
(1.692)^{*}\end{array}$ & $\begin{array}{l}-1.171 \\
(3.023)\end{array}$ & $\begin{array}{l}-0.235 \\
(3.214)\end{array}$ \\
\hline Log population $^{2}$ & $\begin{array}{l}0.424 \\
(0.138)^{* * *}\end{array}$ & $\begin{array}{l}0.523 \\
(0.133)^{* * *}\end{array}$ & $\begin{array}{l}0.266 \\
(0.155)^{*}\end{array}$ & $\begin{array}{l}0.374 \\
(0.180)^{* *}\end{array}$ & $\begin{array}{l}0.179 \\
(0.217)\end{array}$ & $\begin{array}{l}0.512 \\
(0.261)^{*}\end{array}$ & $\begin{array}{l}0.225 \\
(0.543)\end{array}$ & $\begin{array}{l}0.047 \\
(0.580)\end{array}$ \\
\hline Log population $^{3}$ & $\begin{array}{l}-0.019 \\
(0.007)^{* * *}\end{array}$ & $\begin{array}{l}-0.024 \\
(0.007)^{* * *}\end{array}$ & $\begin{array}{l}-0.012 \\
(0.008)\end{array}$ & $\begin{array}{l}-0.018 \\
(0.009)^{* *}\end{array}$ & $\begin{array}{l}-0.007 \\
(0.010)\end{array}$ & $\begin{array}{l}-0.026 \\
(0.013)^{* *}\end{array}$ & $\begin{array}{l}-0.015 \\
(0.032)\end{array}$ & $\begin{array}{l}-0.004 \\
(0.034)\end{array}$ \\
\hline NSW & $\begin{array}{l}0.106 \\
(0.101)\end{array}$ & $\begin{array}{l}0.128 \\
(0.105)\end{array}$ & $\begin{array}{l}-0.036 \\
(0.124)\end{array}$ & $\begin{array}{l}-0.056 \\
(0.144)\end{array}$ & $\begin{array}{l}-0.011 \\
(0.139)\end{array}$ & $\begin{array}{l}-0.075 \\
(0.175)\end{array}$ & $\begin{array}{l}0.148 \\
(0.172)\end{array}$ & $\begin{array}{l}0.245 \\
(0.200)\end{array}$ \\
\hline$\%$ males & $\begin{array}{l}-0.057 \\
(0.421)\end{array}$ & $\begin{array}{l}0.039 \\
(0.431)\end{array}$ & $\begin{array}{l}-0.003 \\
(0.560)\end{array}$ & $\begin{array}{l}0.034 \\
(0.573)\end{array}$ & $\begin{array}{l}-0.147 \\
(0.753)\end{array}$ & $\begin{array}{l}-0.212 \\
(0.777)\end{array}$ & $\begin{array}{l}-0.128 \\
(0.666)\end{array}$ & $\begin{array}{l}-0.171 \\
(0.733)\end{array}$ \\
\hline \%agriculture & $\begin{array}{l}-0.115 \\
(0.508)\end{array}$ & $\begin{array}{l}0.454 \\
(0.576)\end{array}$ & $\begin{array}{l}-0.280 \\
(0.677)\end{array}$ & $\begin{array}{l}0.215 \\
(0.695)\end{array}$ & $\begin{array}{l}-0.078 \\
(0.671)\end{array}$ & $\begin{array}{l}-0.401 \\
(0.990)\end{array}$ & $\begin{array}{l}0.631 \\
(0.919)\end{array}$ & $\begin{array}{l}1.339 \\
(1.034)\end{array}$ \\
\hline$\%$ mining & $\begin{array}{l}-1.425 \\
(0.505)^{* * *}\end{array}$ & $\begin{array}{l}-1.213 \\
(0.527)^{* *}\end{array}$ & $\begin{array}{l}-0.627 \\
(0.659)\end{array}$ & $\begin{array}{l}-0.494 \\
(0.630)\end{array}$ & $\begin{array}{l}-1.038 \\
(0.674)\end{array}$ & $\begin{array}{l}-0.895 \\
(0.764)\end{array}$ & $\begin{array}{l}-0.698 \\
(0.953)\end{array}$ & $\begin{array}{l}-1.340 \\
(1.102)\end{array}$ \\
\hline$\%$ manufacturing & $\begin{array}{l}1.576 \\
(1.745)\end{array}$ & $\begin{array}{l}4.140 \\
(2.369)^{*}\end{array}$ & $\begin{array}{l}3.836 \\
(1.811)^{* *}\end{array}$ & $\begin{array}{l}6.168 \\
(2.176)^{* * *}\end{array}$ & $\begin{array}{l}4.281 \\
(3.555)\end{array}$ & $\begin{array}{l}1.696 \\
(4.555)\end{array}$ & $\begin{array}{l}10.016 \\
(5.052)^{*}\end{array}$ & $\begin{array}{l}11.298 \\
(5.432)^{* * *}\end{array}$ \\
\hline \%working & $\begin{array}{l}1.241 \\
(0.683)^{*}\end{array}$ & $\begin{array}{l}0.654 \\
(0.788)\end{array}$ & $\begin{array}{l}0.448 \\
(0.898)\end{array}$ & $\begin{array}{l}-0.057 \\
(0.885)\end{array}$ & $\begin{array}{l}0.496 \\
(0.968) \\
\end{array}$ & $\begin{array}{l}0.492 \\
(1.206)\end{array}$ & $\begin{array}{l}-1.367 \\
(1.381) \\
\end{array}$ & $\begin{array}{l}-1.758 \\
(1.635) \\
\end{array}$ \\
\hline $\begin{array}{l}\text { Control } \\
\text { function }\end{array}$ & Linear & Quadratic & Linear & Quadratic & Linear & Quadratic & Linear & Quadratic \\
\hline $\begin{array}{l}\mathrm{R}^{2} \\
\mathrm{n}\end{array}$ & $\begin{array}{l}0.35 \\
208\end{array}$ & $\begin{array}{l}0.37 \\
208\end{array}$ & $\begin{array}{l}0.34 \\
139\end{array}$ & $\begin{array}{l}0.39 \\
139\end{array}$ & $\begin{array}{l}0.38 \\
92\end{array}$ & $\begin{array}{l}0.45 \\
92\end{array}$ & $\begin{array}{l}0.47 \\
52\end{array}$ & $\begin{array}{l}0.49 \\
52\end{array}$ \\
\hline
\end{tabular}

Note: Robust standard errors reported in parenthesis. Changes to the definitions of employment and industry definitions, as well as LGA boundaries over time, mean that caution should be used in comparing these coefficients across periods. All values for time varying controls are at the base year. ${ }^{*} \mathrm{p}<0.1, * * \mathrm{p}<0.05, * * * \mathrm{p}<0.01$. 
Table A2: Spatial RD model with covariates (1933-1947)

\begin{tabular}{|c|c|c|c|c|c|c|c|c|}
\hline Variable & & $\mathrm{km}$ & & $\mathrm{km}$ & & $\mathrm{km}$ & 10 & \\
\hline ZTO dummy & $\begin{array}{l}0.110 \\
(0.059) *\end{array}$ & $\begin{array}{l}0.127 \\
(0.068)^{*}\end{array}$ & $\begin{array}{l}0.138 \\
(0.061)^{* *}\end{array}$ & $\begin{array}{l}0.136 \\
(0.073)^{*}\end{array}$ & $\begin{array}{l}0.182 \\
(0.057)^{* * *}\end{array}$ & $\begin{array}{l}0.198 \\
(0.080) * *\end{array}$ & $\begin{array}{l}0.236 \\
(0.085)^{* * *}\end{array}$ & $\begin{array}{l}0.240 \\
(0.105)^{* * *}\end{array}$ \\
\hline Log population & $\begin{array}{l}-3.682 \\
(0.679)^{* * *}\end{array}$ & $\begin{array}{l}-3.821 \\
(0.726)^{* * *}\end{array}$ & $\begin{array}{l}-3.203 \\
(0.862)^{* * *}\end{array}$ & $\begin{array}{l}-3.968 \\
(0.944)^{* * *}\end{array}$ & $\begin{array}{l}-2.414 \\
(0.730)^{* * *}\end{array}$ & $\begin{array}{l}-3.382 \\
(0.883)^{* * *}\end{array}$ & $\begin{array}{l}-4.313 \\
(2.664)\end{array}$ & $\begin{array}{l}-3.715 \\
(2.815)\end{array}$ \\
\hline Log population $^{2}$ & $\begin{array}{l}0.543 \\
(0.101)^{* * *}\end{array}$ & $\begin{array}{l}0.561 \\
(0.109)^{* * *}\end{array}$ & $\begin{array}{l}0.475 \\
(0.127)^{* * *}\end{array}$ & $\begin{array}{l}0.592 \\
(0.140)^{* * *}\end{array}$ & $\begin{array}{l}0.365 \\
(0.106) * * *\end{array}$ & $\begin{array}{l}0.523 \\
(0.133)^{* * *}\end{array}$ & $\begin{array}{l}0.673 \\
(0.457)\end{array}$ & $\begin{array}{l}0.569 \\
(0.485)\end{array}$ \\
\hline Log population $^{3}$ & $\begin{array}{l}-0.025 \\
(0.005)^{* * *}\end{array}$ & $\begin{array}{l}-0.026 \\
(0.005)^{* * *}\end{array}$ & $\begin{array}{l}-0.022 \\
(0.006)^{* * *}\end{array}$ & $\begin{array}{l}-0.028 \\
(0.007)^{* * *}\end{array}$ & $\begin{array}{l}-0.017 \\
(0.005)^{* * *}\end{array}$ & $\begin{array}{l}-0.026 \\
(0.007)^{* * *}\end{array}$ & $\begin{array}{l}-0.034 \\
(0.026)\end{array}$ & $\begin{array}{l}-0.028 \\
(0.027)\end{array}$ \\
\hline NSW & $\begin{array}{l}-0.039 \\
(0.078)\end{array}$ & $\begin{array}{l}0.035 \\
(0.086)\end{array}$ & $\begin{array}{l}-0.036 \\
(0.073)\end{array}$ & $\begin{array}{l}0.111 \\
(0.088)\end{array}$ & $\begin{array}{l}0.007 \\
(0.081)\end{array}$ & $\begin{array}{l}0.104 \\
(0.107)\end{array}$ & $\begin{array}{l}-0.057 \\
(0.122)\end{array}$ & $\begin{array}{l}-0.091 \\
(0.154)\end{array}$ \\
\hline$\%$ males & $\begin{array}{l}-0.095 \\
(0.460)\end{array}$ & $\begin{array}{l}-0.126 \\
(0.444)\end{array}$ & $\begin{array}{l}-0.032 \\
(0.639)\end{array}$ & $\begin{array}{l}0.202 \\
(0.581)\end{array}$ & $\begin{array}{l}-0.436 \\
(0.575)\end{array}$ & $\begin{array}{l}-0.313 \\
(0.592)\end{array}$ & $\begin{array}{l}-1.171 \\
(0.570)^{* *}\end{array}$ & $\begin{array}{l}-1.027 \\
(0.601)^{*}\end{array}$ \\
\hline$\%$ agriculture & $\begin{array}{l}-0.122 \\
(0.292)\end{array}$ & $\begin{array}{l}0.215 \\
(0.278)\end{array}$ & $\begin{array}{l}-0.336 \\
(0.380)\end{array}$ & $\begin{array}{l}0.172 \\
(0.389)\end{array}$ & $\begin{array}{l}0.123 \\
(0.509)\end{array}$ & $\begin{array}{l}0.567 \\
(0.531)\end{array}$ & $\begin{array}{l}0.583 \\
(0.555)\end{array}$ & $\begin{array}{l}0.242 \\
(0.713)\end{array}$ \\
\hline \%mining & $\begin{array}{l}0.270 \\
(0.872)\end{array}$ & $\begin{array}{l}0.753 \\
(0.667)\end{array}$ & $\begin{array}{l}0.110 \\
(1.065)\end{array}$ & $\begin{array}{l}0.667 \\
(0.670)\end{array}$ & $\begin{array}{l}0.312 \\
(1.389)\end{array}$ & $\begin{array}{l}1.992 \\
(1.473)\end{array}$ & $\begin{array}{l}0.499 \\
(14.648)\end{array}$ & $\begin{array}{l}-1.170 \\
(16.852)\end{array}$ \\
\hline$\%$ manufacturing & $\begin{array}{l}-1.216 \\
(1.368)\end{array}$ & $\begin{array}{l}0.316 \\
(1.441)\end{array}$ & $\begin{array}{l}-1.593 \\
(1.926)\end{array}$ & $\begin{array}{l}0.069 \\
(2.136)\end{array}$ & $\begin{array}{l}-3.342 \\
(1.947)^{*}\end{array}$ & $\begin{array}{l}-0.768 \\
(2.668)\end{array}$ & $\begin{array}{l}-3.282 \\
(4.409)\end{array}$ & $\begin{array}{l}-4.709 \\
(5.916)\end{array}$ \\
\hline \%working & $\begin{array}{l}0.507 \\
(0.634) \\
\end{array}$ & $\begin{array}{l}-0.168 \\
(0.604) \\
\end{array}$ & $\begin{array}{l}0.685 \\
(0.771) \\
\end{array}$ & $\begin{array}{l}0.209 \\
(0.767) \\
\end{array}$ & $\begin{array}{l}0.277 \\
(0.930) \\
\end{array}$ & $\begin{array}{l}-0.296 \\
(0.932) \\
\end{array}$ & $\begin{array}{l}-0.322 \\
(1.256) \\
\end{array}$ & $\begin{array}{l}0.670 \\
(1.649) \\
\end{array}$ \\
\hline $\begin{array}{c}\text { Control } \\
\text { function }\end{array}$ & Linear & Quadratic & Linear & Quadratic & Linear & Quadratic & Linear & Quadratic \\
\hline $\begin{array}{l}\mathrm{R}^{2} \\
\mathrm{n}\end{array}$ & $\begin{array}{l}0.21 \\
276\end{array}$ & $\begin{array}{l}0.25 \\
276\end{array}$ & $\begin{array}{l}0.19 \\
173\end{array}$ & $\begin{array}{l}0.27 \\
173\end{array}$ & $\begin{array}{l}0.24 \\
106\end{array}$ & $\begin{array}{l}0.29 \\
106\end{array}$ & $\begin{array}{l}0.43 \\
61\end{array}$ & $\begin{array}{l}0.46 \\
61\end{array}$ \\
\hline
\end{tabular}

Note: See Table A1. 
Table A3: Spatial RD model with covariates (1947-1954)

\begin{tabular}{|c|c|c|c|c|c|c|c|c|}
\hline Variable & \multicolumn{2}{|c|}{$250 \mathrm{~km}$} & \multicolumn{2}{|c|}{$200 \mathrm{~km}$} & \multicolumn{2}{|c|}{$150 \mathrm{~km}$} & \multicolumn{2}{|c|}{$100 \mathrm{~km}$} \\
\hline ZTO dummy & $\begin{array}{l}0.063 \\
(0.050)\end{array}$ & $\begin{array}{l}0.040 \\
(0.056)\end{array}$ & $\begin{array}{l}0.069 \\
(0.048)\end{array}$ & $\begin{array}{l}0.060 \\
(0.052)\end{array}$ & $\begin{array}{l}0.073 \\
(0.053)\end{array}$ & $\begin{array}{l}0.032 \\
(0.056)\end{array}$ & $\begin{array}{l}0.022 \\
(0.061)\end{array}$ & $\begin{array}{l}0.061 \\
(0.075)\end{array}$ \\
\hline Log population & $\begin{array}{l}-0.752 \\
(0.544)\end{array}$ & $\begin{array}{l}-0.991 \\
(0.533)^{*}\end{array}$ & $\begin{array}{l}-0.410 \\
(0.592)\end{array}$ & $\begin{array}{l}-0.768 \\
(0.639)\end{array}$ & $\begin{array}{l}0.156 \\
(0.761)\end{array}$ & $\begin{array}{l}-0.882 \\
(0.791)\end{array}$ & $\begin{array}{l}1.534 \\
(2.871)\end{array}$ & $\begin{array}{l}1.543 \\
(2.844)\end{array}$ \\
\hline Log population ${ }^{2}$ & $\begin{array}{l}0.113 \\
(0.081)\end{array}$ & $\begin{array}{l}0.147 \\
(0.079)^{*}\end{array}$ & $\begin{array}{l}0.060 \\
(0.086)\end{array}$ & $\begin{array}{l}0.114 \\
(0.094)\end{array}$ & $\begin{array}{l}-0.031 \\
(0.109)\end{array}$ & $\begin{array}{l}0.143 \\
(0.117)\end{array}$ & $\begin{array}{l}-0.291 \\
(0.480)\end{array}$ & $\begin{array}{l}-0.299 \\
(0.473)\end{array}$ \\
\hline Log population ${ }^{3}$ & $\begin{array}{l}-0.005 \\
(0.004)\end{array}$ & $\begin{array}{l}-0.007 \\
(0.004)^{*}\end{array}$ & $\begin{array}{l}-0.003 \\
(0.004)\end{array}$ & $\begin{array}{l}-0.006 \\
(0.004)\end{array}$ & $\begin{array}{l}0.002 \\
(0.005)\end{array}$ & $\begin{array}{l}-0.008 \\
(0.006)\end{array}$ & $\begin{array}{l}0.018 \\
(0.026)\end{array}$ & $\begin{array}{l}0.018 \\
(0.026)\end{array}$ \\
\hline NSW & $\begin{array}{l}-0.104 \\
(0.067)\end{array}$ & $\begin{array}{l}-0.036 \\
(0.073)\end{array}$ & $\begin{array}{l}-0.198 \\
(0.063)^{* * *}\end{array}$ & $\begin{array}{l}-0.124 \\
(0.074)^{*}\end{array}$ & $\begin{array}{l}-0.213 \\
(0.062)^{* * *}\end{array}$ & $\begin{array}{l}-0.325 \\
(0.077)^{* * *}\end{array}$ & $\begin{array}{l}-0.334 \\
(0.081)^{* * *}\end{array}$ & $\begin{array}{l}-0.312 \\
(0.108)^{* * *}\end{array}$ \\
\hline$\%$ males & $\begin{array}{l}0.069 \\
(0.181)\end{array}$ & $\begin{array}{l}0.055 \\
(0.173)\end{array}$ & $\begin{array}{l}0.145 \\
(0.230)\end{array}$ & $\begin{array}{l}0.170 \\
(0.236)\end{array}$ & $\begin{array}{l}0.207 \\
(0.409)\end{array}$ & $\begin{array}{l}0.243 \\
(0.390)\end{array}$ & $\begin{array}{l}1.075 \\
(0.371)^{* * *}\end{array}$ & $\begin{array}{l}1.003 \\
(0.389)^{* *}\end{array}$ \\
\hline \%agriculture & $\begin{array}{l}-0.193 \\
(0.255)\end{array}$ & $\begin{array}{l}-0.090 \\
(0.254)\end{array}$ & $\begin{array}{l}-0.351 \\
(0.268)\end{array}$ & $\begin{array}{l}-0.234 \\
(0.287)\end{array}$ & $\begin{array}{l}-0.465 \\
(0.326)\end{array}$ & $\begin{array}{l}-0.640 \\
(0.369)^{*}\end{array}$ & $\begin{array}{l}-0.615 \\
(0.427)\end{array}$ & $\begin{array}{l}-0.642 \\
(0.420)\end{array}$ \\
\hline$\%$ mining & $\begin{array}{l}-1.227 \\
(0.519)^{* *}\end{array}$ & $\begin{array}{l}-0.972 \\
(0.502)^{*}\end{array}$ & $\begin{array}{l}-0.645 \\
(0.393)\end{array}$ & $\begin{array}{l}-0.593 \\
(0.370)\end{array}$ & $\begin{array}{l}-0.751 \\
(0.459)\end{array}$ & $\begin{array}{l}-0.861 \\
(0.471)^{*}\end{array}$ & $\begin{array}{l}-1.247 \\
(0.406)^{* * *}\end{array}$ & $\begin{array}{l}-0.840 \\
(0.482)^{*}\end{array}$ \\
\hline$\%$ manufacturing & $\begin{array}{l}-1.189 \\
(0.618)^{*}\end{array}$ & $\begin{array}{l}-0.166 \\
(0.733)\end{array}$ & $\begin{array}{l}-1.263 \\
(0.602)^{* *}\end{array}$ & $\begin{array}{l}-0.467 \\
(0.780)\end{array}$ & $\begin{array}{l}-1.789 \\
(1.622)\end{array}$ & $\begin{array}{l}-3.732 \\
(2.084)^{*}\end{array}$ & $\begin{array}{l}-0.762 \\
(2.920)\end{array}$ & $\begin{array}{l}0.371 \\
(5.239)\end{array}$ \\
\hline \%working & $\begin{array}{l}0.410 \\
(0.370) \\
\end{array}$ & $\begin{array}{l}0.504 \\
(0.332) \\
\end{array}$ & $\begin{array}{l}0.185 \\
(0.344) \\
\end{array}$ & $\begin{array}{l}0.344 \\
(0.336) \\
\end{array}$ & $\begin{array}{l}-0.391 \\
(0.299) \\
\end{array}$ & $\begin{array}{l}-0.484 \\
(0.355) \\
\end{array}$ & $\begin{array}{l}0.100 \\
(0.557) \\
\end{array}$ & $\begin{array}{l}0.377 \\
(0.696) \\
\end{array}$ \\
\hline $\begin{array}{l}\text { Control } \\
\text { function }\end{array}$ & Linear & Quadratic & Linear & Quadratic & Linear & Quadratic & Linear & Quadratic \\
\hline $\begin{array}{l}\mathrm{R}^{2} \\
\mathrm{n}\end{array}$ & $\begin{array}{l}0.09 \\
299\end{array}$ & $\begin{array}{l}0.14 \\
299\end{array}$ & $\begin{array}{l}0.12 \\
184\end{array}$ & $\begin{array}{l}0.16 \\
184\end{array}$ & $\begin{array}{l}0.19 \\
113\end{array}$ & $\begin{array}{l}0.26 \\
113\end{array}$ & $\begin{array}{l}0.42 \\
64\end{array}$ & $\begin{array}{l}0.44 \\
64\end{array}$ \\
\hline
\end{tabular}

Note: See Table A1. 
Table A4: Spatial RD model with covariates (1954-1961)

\begin{tabular}{|c|c|c|c|c|c|c|c|c|}
\hline Variable & \multicolumn{2}{|c|}{$250 \mathrm{~km}$} & \multicolumn{2}{|c|}{$200 \mathrm{~km}$} & \multicolumn{2}{|c|}{$150 \mathrm{~km}$} & \multicolumn{2}{|c|}{$100 \mathrm{~km}$} \\
\hline ZTO dummy & $\begin{array}{l}-0.047 \\
(0.046)\end{array}$ & $\begin{array}{l}0.010 \\
(0.049)\end{array}$ & $\begin{array}{l}-0.046 \\
(0.046)\end{array}$ & $\begin{array}{l}0.039 \\
(0.050)\end{array}$ & $\begin{array}{l}-0.007 \\
(0.048)\end{array}$ & $\begin{array}{l}0.067 \\
(0.058)\end{array}$ & $\begin{array}{l}-0.016 \\
(0.061)\end{array}$ & $\begin{array}{l}0.032 \\
(0.067)\end{array}$ \\
\hline Log population & $\begin{array}{l}-1.463 \\
(0.347)^{* * *}\end{array}$ & $\begin{array}{l}-1.308 \\
(0.385)^{* * *}\end{array}$ & $\begin{array}{l}-1.041 \\
(0.361)^{* * *}\end{array}$ & $\begin{array}{l}-1.305 \\
(0.420)^{* * *}\end{array}$ & $\begin{array}{l}-0.128 \\
(0.697)\end{array}$ & $\begin{array}{l}-1.235 \\
(0.700)^{*}\end{array}$ & $\begin{array}{l}-2.104 \\
(2.105)\end{array}$ & $\begin{array}{l}-2.735 \\
(1.886)\end{array}$ \\
\hline Log population $^{2}$ & $\begin{array}{l}0.221 \\
(0.053) * * *\end{array}$ & $\begin{array}{l}0.198 \\
(0.060)^{* * *}\end{array}$ & $\begin{array}{l}0.153 \\
(0.055)^{* * *}\end{array}$ & $\begin{array}{l}0.199 \\
(0.065) * * *\end{array}$ & $\begin{array}{l}0.017 \\
(0.105)\end{array}$ & $\begin{array}{l}0.198 \\
(0.109)^{*}\end{array}$ & $\begin{array}{l}0.367 \\
(0.358)\end{array}$ & $\begin{array}{l}0.456 \\
(0.323)\end{array}$ \\
\hline Log population ${ }^{3}$ & $\begin{array}{l}-0.010 \\
(0.003)^{* * *}\end{array}$ & $\begin{array}{l}-0.009 \\
(0.003)^{* * *}\end{array}$ & $\begin{array}{l}-0.007 \\
(0.003)^{* *}\end{array}$ & $\begin{array}{l}-0.009 \\
(0.003)^{* * *}\end{array}$ & $\begin{array}{l}-0.000 \\
(0.005)\end{array}$ & $\begin{array}{l}-0.010 \\
(0.006)^{*}\end{array}$ & $\begin{array}{l}-0.020 \\
(0.020)\end{array}$ & $\begin{array}{l}-0.024 \\
(0.018)\end{array}$ \\
\hline NSW & $\begin{array}{l}-0.050 \\
(0.052)\end{array}$ & $\begin{array}{l}-0.059 \\
(0.053)\end{array}$ & $\begin{array}{l}-0.010 \\
(0.055)\end{array}$ & $\begin{array}{l}-0.027 \\
(0.064)\end{array}$ & $\begin{array}{l}-0.044 \\
(0.059)\end{array}$ & $\begin{array}{l}0.010 \\
(0.070)\end{array}$ & $\begin{array}{l}-0.019 \\
(0.085)\end{array}$ & $\begin{array}{l}0.101 \\
(0.112)\end{array}$ \\
\hline$\%$ males & $\begin{array}{l}0.371 \\
(0.244)\end{array}$ & $\begin{array}{l}0.437 \\
(0.253)^{*}\end{array}$ & $\begin{array}{l}0.275 \\
(0.277)\end{array}$ & $\begin{array}{l}0.433 \\
(0.302)\end{array}$ & $\begin{array}{l}0.122 \\
(0.503)\end{array}$ & $\begin{array}{l}0.185 \\
(0.443)\end{array}$ & $\begin{array}{l}-0.229 \\
(0.598)\end{array}$ & $\begin{array}{l}-0.256 \\
(0.574)\end{array}$ \\
\hline \%agriculture & $\begin{array}{l}-0.063 \\
(0.212)\end{array}$ & $\begin{array}{l}-0.149 \\
(0.261)\end{array}$ & $\begin{array}{l}0.013 \\
(0.261)\end{array}$ & $\begin{array}{l}-0.038 \\
(0.308)\end{array}$ & $\begin{array}{l}-0.001 \\
(0.318)\end{array}$ & $\begin{array}{l}0.047 \\
(0.351)\end{array}$ & $\begin{array}{l}-0.149 \\
(0.552)\end{array}$ & $\begin{array}{l}-0.172 \\
(0.482)\end{array}$ \\
\hline$\%$ mining & $\begin{array}{l}-0.332 \\
(0.342)\end{array}$ & $\begin{array}{l}-0.388 \\
(0.383)\end{array}$ & $\begin{array}{l}-0.590 \\
(0.743)\end{array}$ & $\begin{array}{l}0.063 \\
(0.828)\end{array}$ & $\begin{array}{l}-1.722 \\
(1.111)\end{array}$ & $\begin{array}{l}-0.419 \\
(1.158)\end{array}$ & $\begin{array}{l}-8.997 \\
(8.554)\end{array}$ & $\begin{array}{l}-0.303 \\
(6.819)\end{array}$ \\
\hline$\%$ manufacturing & $\begin{array}{l}-0.553 \\
(0.652)\end{array}$ & $\begin{array}{l}-0.583 \\
(0.781)\end{array}$ & $\begin{array}{l}-0.349 \\
(0.670)\end{array}$ & $\begin{array}{l}-0.012 \\
(0.884)\end{array}$ & $\begin{array}{l}-4.805 \\
(2.434) *\end{array}$ & $\begin{array}{l}-3.159 \\
(2.436)\end{array}$ & $\begin{array}{l}-4.204 \\
(3.061)\end{array}$ & $\begin{array}{l}0.110 \\
(2.838)\end{array}$ \\
\hline \%working & $\begin{array}{l}0.309 \\
(0.496)\end{array}$ & $\begin{array}{l}0.322 \\
(0.621)\end{array}$ & $\begin{array}{l}-0.011 \\
(0.640)\end{array}$ & $\begin{array}{l}0.019 \\
(0.758)\end{array}$ & $\begin{array}{l}-0.861 \\
(1.164)\end{array}$ & $\begin{array}{l}-0.847 \\
(1.053)\end{array}$ & $\begin{array}{l}-0.759 \\
(1.919)\end{array}$ & $\begin{array}{l}0.398 \\
(1.515)\end{array}$ \\
\hline $\begin{array}{l}\text { Control } \\
\text { function }\end{array}$ & Linear & Quadratic & Linear & Quadratic & Linear & Quadratic & Linear & Quadratic \\
\hline $\begin{array}{l}\mathrm{R}^{2} \\
\mathrm{n}\end{array}$ & $\begin{array}{l}0.11 \\
295\end{array}$ & $\begin{array}{l}0.14 \\
295\end{array}$ & $\begin{array}{l}0.09 \\
185\end{array}$ & $\begin{array}{l}0.16 \\
185\end{array}$ & $\begin{array}{l}0.19 \\
112\end{array}$ & $\begin{array}{l}0.32 \\
112\end{array}$ & $\begin{array}{l}0.27 \\
63\end{array}$ & $\begin{array}{l}0.38 \\
63\end{array}$ \\
\hline
\end{tabular}

Note: See Table A1. 
Table A5: Change in male population share 1933-47 (spatial RD model)

\begin{tabular}{|c|c|c|c|c|c|c|c|c|}
\hline \multirow[t]{2}{*}{ Variable } & \multicolumn{2}{|c|}{$250 \mathrm{~km}$} & \multicolumn{2}{|c|}{$200 \mathrm{~km}$} & \multicolumn{2}{|c|}{$150 \mathrm{~km}$} & \multicolumn{2}{|c|}{$100 \mathrm{~km}$} \\
\hline & \multicolumn{7}{|c|}{ Dependent variable $=\Delta$ male population share $1933-47$} & \\
\hline ZTO dummy & $\begin{array}{l}0.018 \\
(0.017)\end{array}$ & $\begin{array}{l}0.013 \\
(0.018)\end{array}$ & $\begin{array}{l}0.009 \\
(0.019)\end{array}$ & $\begin{array}{l}0.010 \\
(0.018)\end{array}$ & $\begin{array}{l}0.000 \\
(0.016)\end{array}$ & $\begin{array}{l}0.012 \\
(0.017)\end{array}$ & $\begin{array}{l}0.007 \\
(0.020)\end{array}$ & $\begin{array}{l}0.013 \\
(0.025)\end{array}$ \\
\hline $\begin{array}{l}\text { Control } \\
\text { function }\end{array}$ & Linear & Quadratic & Linear & Quadratic & Linear & Quadratic & Linear & Quadratic \\
\hline $\mathrm{R}^{2}$ & 0.04 & 0.05 & 0.05 & 0.07 & 0.03 & 0.09 & 0.03 & 0.11 \\
\hline $\mathrm{n}$ & 324 & 324 & 201 & 201 & 128 & 128 & 74 & 74 \\
\hline
\end{tabular}

Note: Robust standard errors reported in parenthesis. ${ }^{*} \mathrm{p}<0.1,{ }^{*} \mathrm{p}<0.05,{ }^{*} * \mathrm{p}<0.01$. 